\title{
Endemism in Italian Orthoptera
}

\author{
Bruno Massa' \& Paolo Fontana ${ }^{2 *}$ \\ 1'Department Agriculture, Food and Forest Sciences, University of Palermo, Italy (retired); email: bruno.massa@unipa.it \\ ${ }^{2}$ Fondazione Edmund Mach, San Michele all'Adige, Italy \\ *Corresponding author, email: paolo_api.fontana@fmach.it
}

\begin{abstract}
The present paper discusses about the distribution of orthopterans endemic to Italy. This country is located in the centre of the Mediterranean Basin and its palaeo-geographical origins are owed to complex natural phenomena, as well as to a multitude of centres-of-origin, where colonization of fauna and flora concerned. Out of 382 Orthoptera taxa (i.e., species and subspecies) known to occur in Italy, 160 (41.9\%) are endemic. Most of them are restricted to the Alps, the Apennines or the two principal islands of Italy (i.e., Sardinia and Sicily). In addition, lowland areas in central-southern Italy host many endemic taxa, which probably originate from the Balkan Peninsula. In Italy, the following 8 genera are considered endemic: Sardoplatycleis, Acroneuroptila, Italopodisma, Epipodisma, Nadigella, Pseudoprumna, Chorthopodisma and Italohippus. Moreover, the subgenus Italoptila is endemic to Italy. For research regarding endemism, Orthoptera are particularly interesting because this order comprises species characterized by different ecological traits; e.g., different dispersal abilities, contrasting thermal requirements or specific demands on their habitats. The highest percentage of apterous or micropterous (35.3\%) and brachypterous (16.2\%) endemic taxa live in the Apennines, which are among the most isolated mountains of the Italian Peninsula. Finally, some endemic species are endangered at the European scale.
\end{abstract}

KEY WORDS $\quad$ Endemic taxa; insularity; isolation; islands; peninsula; mountains; Italy; Alps; Apennines.

Received 05.04.2020; accepted 21.04.2020; published online 28.04.2020.

\section{INTRODUCTION}

In Europe, the degree of endemism in Orthoptera is generally high $(68.3 \%$ according to Hochkirch et al., 2016). In Italy, according to the most recent contributions to the Italian Orthoptera (Massa et al., 2012; Baroni et al., 2018), overall 160 of 382 (i.e, $41.9 \%$ ) taxa are endemic. The origin of these taxa may be mainly due to ancient geographic isolation, which occurred at different stages during earth's history. As a consequence, novel species may have evolved from separated sub-populations which were isolated from other populations for a long time period. High mountains (Alps, Apennines and other isolated areas of high elevation) as well as islands have thus frequently contributed considerably to the evolution of endemic species among Italian Orthoptera. The geodynamic development and rapid paleo-biological changes occurring in the Oligocene played an important role in the evolution of endemic taxa (Steininger \& Wessely, 2000). In the early Pliocene, the Mediterranean region was dominated by arid and semi-arid habitats (Suc et al., 1995). These conditions have likely contributed to the evolution of endemic taxa adapted to arid conditions (Verdú \& Galante, 2002). During the Pleistocene, thermophilous and psychrophilous species were able to survive in different parts of the Mediterranean in disjunct populations that underwent genetic isolation (Vargas et al., 1998; Baquero \& Telleria, 2001; Bat- 
tisti, 2014). In the Quaternary, the southern Mediterranean peninsulas included hotspots of species richness and endemism. Sea level oscillations and glaciations have been suggested as the main factors of many range disjunctions in Italian butterflies (Racheli \& Zilli, 1985). Northern Orthoptera species that remained in isolated populations in southern Italy during the last glacial period (approxiamtely 18,000 years ago) are now recognized as glacial relicts (e.g., Gomphocerus sibiricus, which in Italy, currently occurs only in the Alps and Apennines, but which is widespread in the Palaearctic).

The Italian Peninsula is characterized by unique physiographic conditions, which includes the presence of high mountains (Apennines) along the main North-South orientation of the peninsula. The unique shape of the Italian peninsula has been the subject of biogeographical interest by different authors, especially concerning the North-South gradient of impoverishment (e.g., Massa, 1982; Battisti 2006, 2014). The Italian peninsula has two distinct southern tips, in Apulia and in Calabria, respectively, each with very different landscapes (mainly lowlands in Apulia and mountain systems in Calabria). This heterogeneity has probably contributed to the increase of taxonomical diversity in the area. Orthoptera are interesting model organisms as this order includes species with very different dispersal abilities, due to differences in wing development, contrasting habitat preferences, thermophily (Marini et al., 2008). Concerning wing length, many taxa among Italian Orthoptera are wingless, micropterous or brachypterous (158 among the endemic taxa) and this may have increased the degree of geographic isolation during their evolution.

Italy is located in the centre of the Mediterranean Basin and its palaeo-geographical origins are owed to complex natural phenomena, as well as to the close proximity to a multitude of centres-oforigin, where colonization of fauna and flora concerned. Moreover, the Mediterranean Sea in the east and west of the Italian Peninsula represents a natural barrier for Orthoptera species, which may have limited species' dispersal. Italian Orthoptera can be classified by their frequency and range size: (i) abundant and widespread all over the country (e.g., Tettigonia viridissima or Anacridium aegyptium); (ii) scattered occurrence in particular habitats, but not differentiated compared to other European populations (e.g., Gomphocerus sibiricus or Chorthip- pus pullus); (iii) endemic species, which are restricted to particular areas of Italy (e.g., Decticus loudoni or Italopodisma samnitica). Some of the endemic taxa are represented by allopatric populations, which have been classified as species or subspecies, characterized by one of the following conditions: (i) a unique geographic range or habitat, (ii) a group of phylogenetically concordant arrays of phenotypic and genetic characters, (iii) a unique natural history but low genetic divergence (cf. O'Brien \& Mayr, 1991). The absence of gene flow in these allopatric populations have increased genetic differences to other related species. Especially, gene-flow between island and continental populations is strongly reduced (e.g., Fontana \& Odé, 1999; Allegrucci et al., 2013). Consequently, we expect that they diverge genetically at a faster rate than continental populations. The same applies to isolated populations on mountain tops (e.g., Fontana \& La Greca, 1999b).

In the present paper, we present a review of endemic Italian orthopterans (see also Massa et al., 2001)

\section{MATERIAL AND METHODS}

According to Minelli (1974) and Anderson (1994), endemism describes a taxon whose distribution is limited to a geographically confined territory, often small and localized. Thus, a species (or other taxon) is endemic to a biogeographic region if it only occurs in that area. Neverthelesss, these areas may differ in size.

The present paper is based on the Italian Orthoptera database which has formerly been used to publish some monographs on Italian Orthoptera (Kleukers et al., 1997; Fontana et al., 1999, 2016; Fontana \& Massa, 2000; La Greca et al., 2000; Massa et al., 2001, 2012; Massa \& Fontana, 2011; Iorio et al., 2019) and to contribute to the Red List of European Orthoptera (Hochkirch et al., 2016). Species and genera that are exclusively alpine but do occur also outside Italy were also included in our study. Appendix 1 lists all the Italian Orthoptera, including information on endemism and European threat status (Hochkirch et al., 2016). Italy has not carried out a Red List of Orthoptera, thus information on the staus of Italian Orthoptera is drawn from the Red List of European Orthoptera (Hochkirch et al., 
2016). Nomenclature follows the Orthoptera Species File (Cigliano et al., online). For practical reasons, the Italian territory was divided into five biogeographic regions: (i) Alps southwards to the Po Valley; (ii) Apennines; (iii) the Italian Peninsula south from the Po Valley (Apennines excluded) (iv) Sardinia and (v) Sicily (small circum-Sicilian islands included) (Figs. 1-3). For each of these areas the Index of Endemism (EI) was calculated as follows:

Index of endemism $(E I)=$ Number of endemic taxa/Total number of Italian taxa X 100

The same index has been calculated for each biogeographic region by dividing by the total number of regionally occurring taxa of the concerned area.

\section{RESULTS AND DISCUSSION}

Out of 382 Orthoptera taxa (i.e., species and subspecies) known to occur in Italy, 160 (41.9\%) are endemic (Fig. 4). The total number of species found in the biogerographic regions of Italy is reported in the Table 1.

\section{Endemism on the islands of Sicily and Sar- dinia}

[Sicilian taxa here considered: Leptophyes sicula, Odontura arcuata, Platycleis concii, Platycleis ragusai, Tessellana lagrecai, Incertana drepanensis, Eupholidoptera bimucronata, Ctenodecticus siculus, Ephippiger camillae, Uromenus bonneti painoi, Uromenus brevicollis trinacriae, Uromenus riggioi, Uromenus siculus, Gryllotalpa cossyrensis (Pantelleria Is.), Pamphagus marmoratus, Pamphagus ortolanii (Lampedusa Is.), Acinipe galvagnii, Ochrilidia sicula, Dociostaurus minutus, Omocestus lopadusae (Lampedusa Is.), Chorthippus brunneus raggei, Chorthippus messinai, Chorthippus trinacriae, Euchorthippus albolineatus siculus]

[Sardinian taxa here considered: Odontura calaritana, Tettigonia longispina, Sardoplatycleis galvagnii, Rhacocleis baccettii, Rhacocleis corsicana, Rhacocleis maculipedes, Ctenodecticus bolivari bolivari, Uromenus annae, Uromenus brevicollis insularis, Dolichopoda muceddai, Acroneuroptila puddui,
Acroneuroptila sardoa, Gryllotalpa vigintiunum, Pamphagus sardeus, Oedipoda caerulescens sardeti, Oedipoda fuscocincta morini, Sphingonotus candidus candidus, Sphingonotus uvarovi, Ochrilidia nuragica, Euchorthippus sardous]

In spite of only small differences in their area (Sardinia: $24,090 \mathrm{~km}^{2}$, Sicily: $25,709 \mathrm{~km}^{2}$ ), the two islands differ substantially in their total number of Orthoptera species (98 and 127 species, respectively) recorded up to now. This may be due to both the higher degree of geographical isolation of Sardinia as well as the lower level of knowledge of orthopterofauna in this region. In total, 25 taxa are endemic to Sicily, whereas among the Sardinian orthopterans 19 taxa are endemic (EI: see Table 1). These data confirm the importance of Mediterranean islands as hotspots of biodiversity (Médail \& Quézel, 1999).

It is difficult to evaluate if the presence of species endemic to these islands is relictual or due to passive dispersal, such as human introduction. For example, Metaplastes pulchripennis, present in many regions of Italy and neighbouring countries, has been also found in the Nebrodi Mountains on Sicily. Since there is no morphological difference between Sicilian and peninsular populations of this species, it is hard to assess whether its presence on the island represents an ancient relict population of mainland provenance or a more recently established population. Genetic analyses might help to gain more knowledge on this issue. Similarly, it is difficult to answer whether Metaplastes ippolitoi, described by La Greca (1949) from Calabria and recently found in the Madonie Mountains on Sicily by Fontana et al. (2004), was accidentally introduced to Sicily or whether its presence on this island reflects a formerly wider distribution.

Until 2010, Leptophyes sicula which is endemic to Siciliy, was prreviously considered as a population of the widespread European species L. punctatissima. The micropterous genus Leptophyes includes many morphologically similar species that can be distinguished by their stridulatory songs (Kleukers et al., 2010). Eupholidoptera bimucronata (morphologically related to the Italian E. magnifica), two species of Platycleis (P. ragusai and P. concii), Tessellana lagrecai (morphologically related to, if not conspecific with, T. tessellata, widespread in Eurasia and North Africa), Ephippiger camillae (known only 


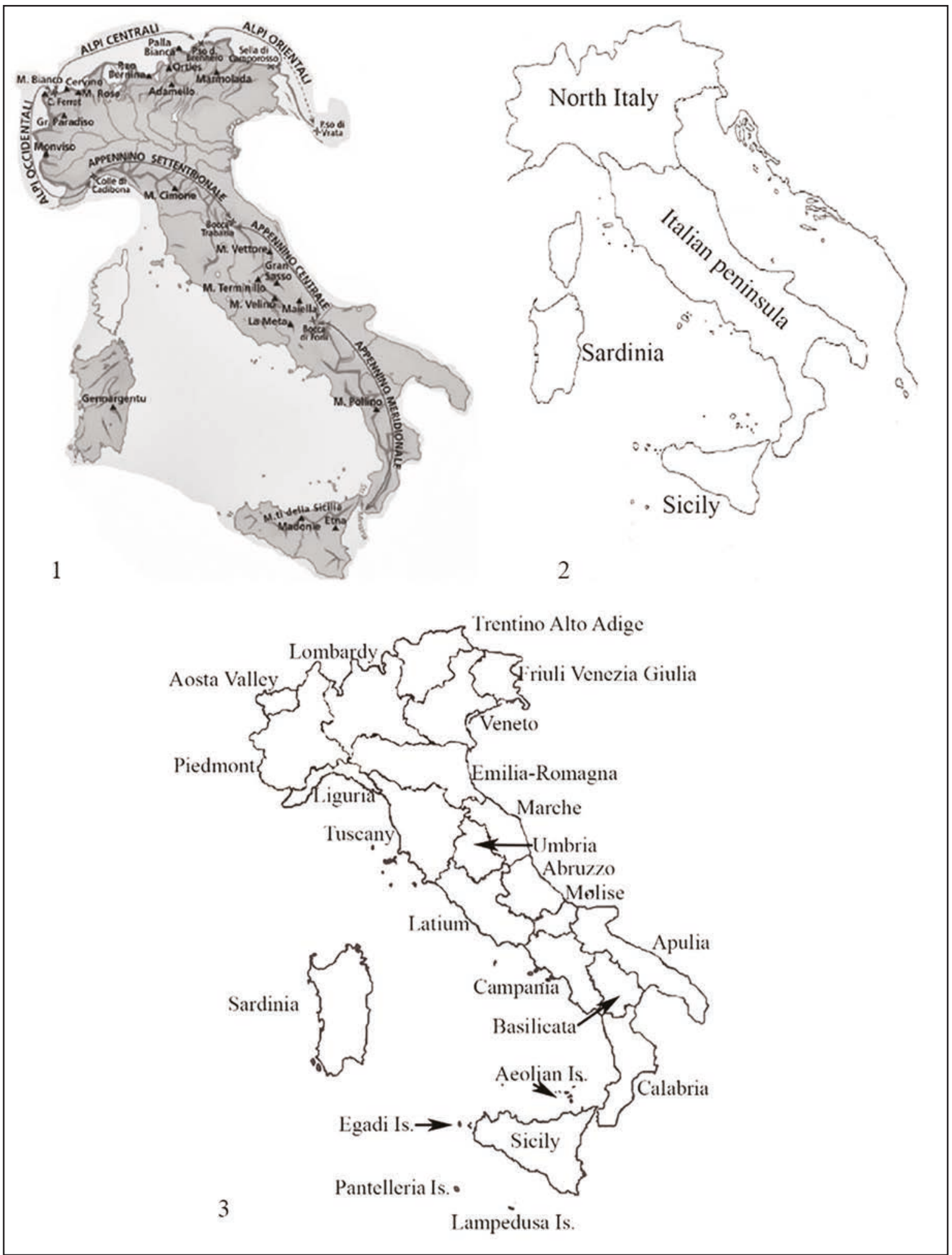

Figure 1. Physical map of Italy, showing Alps, northern, central, and southern Apennines, and the islands of Sicily and Sardinia. Figure 2. Boundaries of northern Italy (from Alps to Po Valley), Italian Peninsula, Sardinia, and Sicily. Figure 3. Map of Italy showing all the regions. 


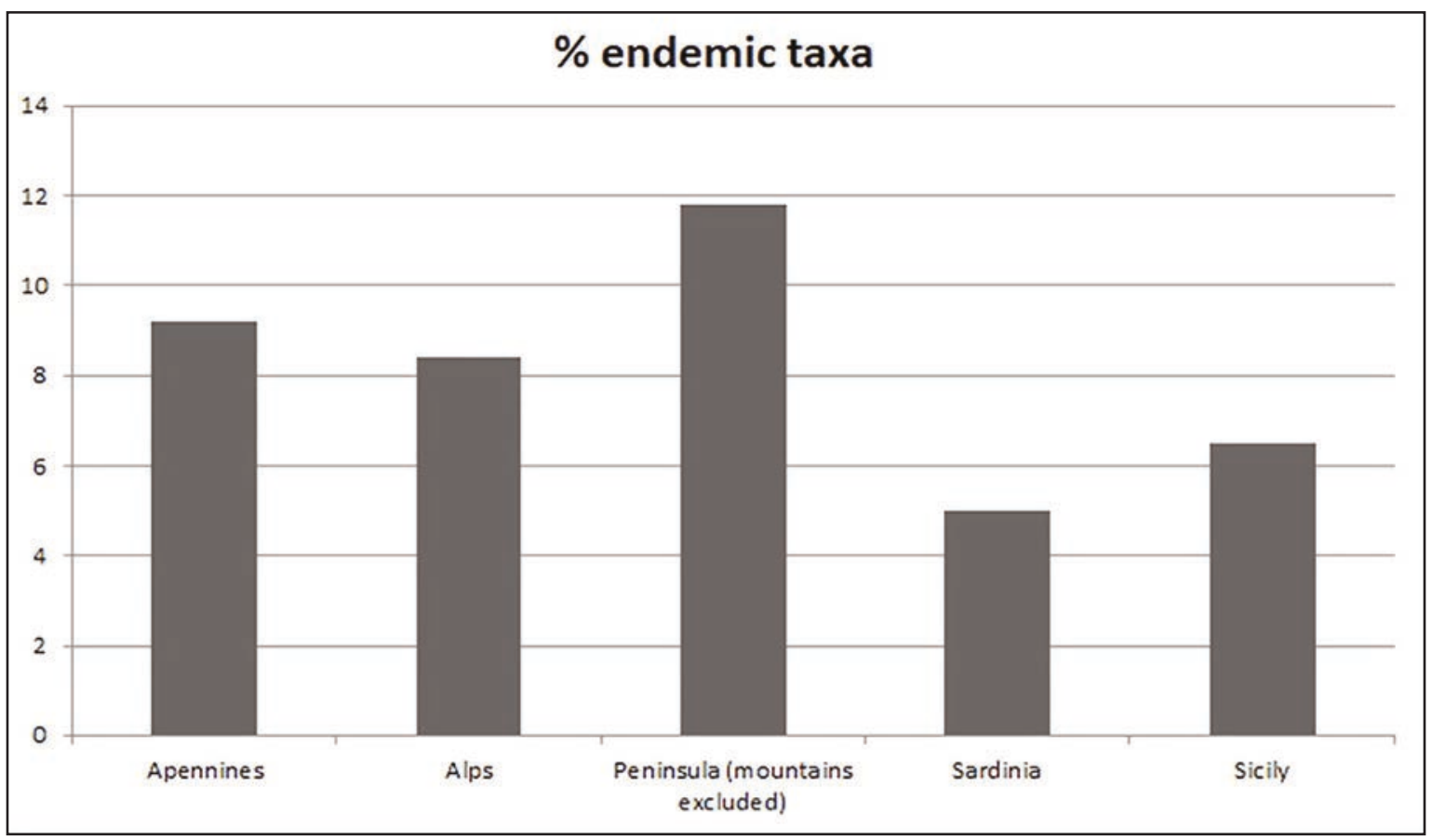

Figure 4. Percentage of endemic species of Orthoptera in different areas of Italy.

\begin{tabular}{|c|c|c|c|c|c|}
\hline & Alps & Apennines & $\begin{array}{c}\text { Peninsular } \\
\text { Italy } \\
\text { Apennines } \\
\text { excluded) }\end{array}$ & Sicily & Sardinia \\
\hline Ensifera & 56 & 40 & 108 & 72 & 55 \\
\hline Caelifera & 52 & 28 & 80 & 55 & 43 \\
\hline Total & 108 & 68 & 188 & 127 & 98 \\
\hline $\begin{array}{c}\text { EI of Italian } \\
\text { orthopterofauna }\end{array}$ & $8.4 \%$ & $9.2 \%$ & $11.8 \%$ & $6.5 \%$ & $5.0 \%$ \\
\hline $\begin{array}{c}\text { EI of orthopterofauna of } \\
\text { concerned areas }\end{array}$ & $29.6 \%$ & $51.5 \%$ & $23.9 \%$ & $19.7 \%$ & $19.4 \%$ \\
\hline $\begin{array}{c}\text { Apterous or Micropterous } \\
\text { taxa }\end{array}$ & $21(19.2 \%)$ & $24(35.3 \%)$ & $33(17.5 \%)$ & $13(10.2 \%)$ & $10(10.2 \%)$ \\
\hline Brachypterous taxa & $13(11.9 \%)$ & $11(16.2 \%)$ & $7(3.7 \%)$ & $7(5.5 \%)$ & $1(1.0 \%)$ \\
\hline Long-winged taxa & 0 & 0 & $5(2.6 \%)$ & $5(3.9 \%)$ & $8(8.2 \%)$ \\
\hline
\end{tabular}

Table 1. Total number of taxa in the Alps, Apennines, Peninsular Italy, Sicily and Sardinia; percentage of endemic Orthoptera calculated with the Index of Endemism (see methods) on the whole Italian orthopterofauna and in the concerned areas; number of apterous or micropterous, brachypterous and long-winged taxa within the endemic taxa in the concerned areas (in parenthesis the percentage on the total number of taxa known from the area). Source: Massa et al. (2012), Iorio et al. (2019). 
from the holotype, collected in the Madonie Mountains), Uromenus siculus (morphologically related to $U$. elegans from Italy and the Balkan peninsula), and three taxa of the genus Chorthippus (C. brunneus raggei, C. messinai, C. trinacriae) may be considered as allopatric subpopulations, maintained by spatial segregation as a result of vicariance events during recent earth's history.

The genus Odontura, which has a Western Mediterranean distribution, including the Iberian peninsula and North Africa (Warchalowska-Sliwa et al., 2011; Grzywacz et al., 2013), is present in both Sicily and Sardinia with two endemic species: Odontura arcuata (which can be distinguished from Odontura stenoxypha, occurring in Sicily and North Africa, only chromosomally, cf. Messina, 1981) and Odotura calaritana. According to Grzywacz et al., (2013), O. arcuata should be considered as a subspecies of $O$. stenoxypha, but the populations of both species do probably overlap.

Other species with similar distributional patterns are: Tettigonia longispina from Sardinia, morphologically related to the Maghrebian T. savignyi; Uromenus annae from Sardinia, related to the North African species U. bouiblani (Nadig, 1995) from north Morocco, U. i. innocentii (Bonnet \& Finot, 1885) from Morocco, Algeria, and Tunisia, and $U . m$. moulouyae (Nadig, 1995) from Morocco (Buzzetti et al., 2019); Pamphagus sardeus, related to the Tunisian P. tunetanus Vosseler, 1902 and to $P$. ortolanii from the island of Lampedusa (that was physically connected to Tunisia up to at least 16,000 years ago); P. marmoratus, a Sicilian endemic morphologically related to western Maghrebian species distributed in Algeria and Morocco [e.g. P. elephas (L., 1758) and P. caprai Massa, 1992]; Pterolepis elymica from Sicily, related to Pterolepis pedata from Sardinia, Lampedusa and Tunisia; Ctenodecticus b. bolivari from Sardinia (C. b. africanus Galvagni, 1990 lives in Tunisia); C. siculus from Sicily; Ochrilidia sicula from Sicily and $O$. nuragica from Sardinia [both morphologically related to the Afro-Asian $O$. geniculata (Bolívar, 1913)]; Uromenus brevicollis trinacriae from Sicily and $U$. brevicollis insularis from Sardinia, both morphologically similar to the north African U. b. brevicollis (Fischer, 1853).

Incertana drepanensis from Sicily is the sole Italian representative of a genus widespread from the Middle East to North Africa and the Iberian Peninsula; Acinipe galvagnii from Sicily is related to $A$. hesperica Rambur, 1838, a North African and Iberian species. Another species of Acinipe, A. cala$b r a$, is distributed in Calabria, Sicily, and North Africa. Uromenus bonneti is present in Tunisia, on the island of Lampedusa (U. b. bonneti) and in Sicily (Uromenus bonneti painoi). Dociostaurus minutus from Sicily and Omocestus lopadusae from Lampedusa are related to the North African brachypterous species Dociostaurus dantini Bolívar, 1914 and Omocestus fontanai Massa, 2004. Furthermore, Euchorthippus albolineatus siculus is endemic to Sicily, while the typical form (E. a. albolineatus) is distributed in North Africa. By contrast, it is difficult to find morphological relations between Uromenus riggioi and any Maghrebian species.

Interestingly, Sardinia, which is more isolated than Sicily, holds some endemic taxa with no clear morphological similarities to other European (including Corsica island) and African taxa: Sardoplatycleis galvagnii (endemic genus), Rhacocleis baccettii, R. maculipedes, Acroneuroptila puddui, Acroneuroptila sardoa, Sphingonotus uvarovi, and the brachypterous species Euchorthippus sardous.

\section{Endemism in the Alps and Apennines}

[Italian endemic taxa from Alps here considered, including those present also in Switzerland, Austria and France: Barbitistes vicetinus, Anonconotus pusillus, A.alpinus, A. baracunensis, A. ghilianii, A. italoaustriacus, A. ligustinus, A. occidentalis, Chopardius pedestris apuanus, Pholidoptera littoralis insubrica, Ephippiger persicarius, Ephippiger terrestris spp., Podisma d. dechambrei, Podisma dechambrei melisi, Podisma eitschbergeri, Podisma pedestris nadigi, Podisma pedestris caprai, Miramella alpina, Nadigella f. formosanta, Nadigella formosanta bessae, Kisella irena, Pseudoprumna baldensis, Chortopodisma cobellii, Epipodisma pedemontana, Odontopodisma decipiens insubrica, Pararcyptera alzonai, Stenobothrus ursulae. Stenobotrhus cotticus, Chorthippus cialancensis, C. sampeyrensis, C. a. alticola, C. alticola rammei, Chorthippus mollis ignifer, Chorthippus saulcyi daimei]

[Endemic taxa from Apennines here considered: Tettigonia silana, Decticus aprutianus, Metrioptera caprai caprai, Metrioptera caprai baccettii, Metrioptera caprai galvagnii, Metrioptera caprai lagrecai, 

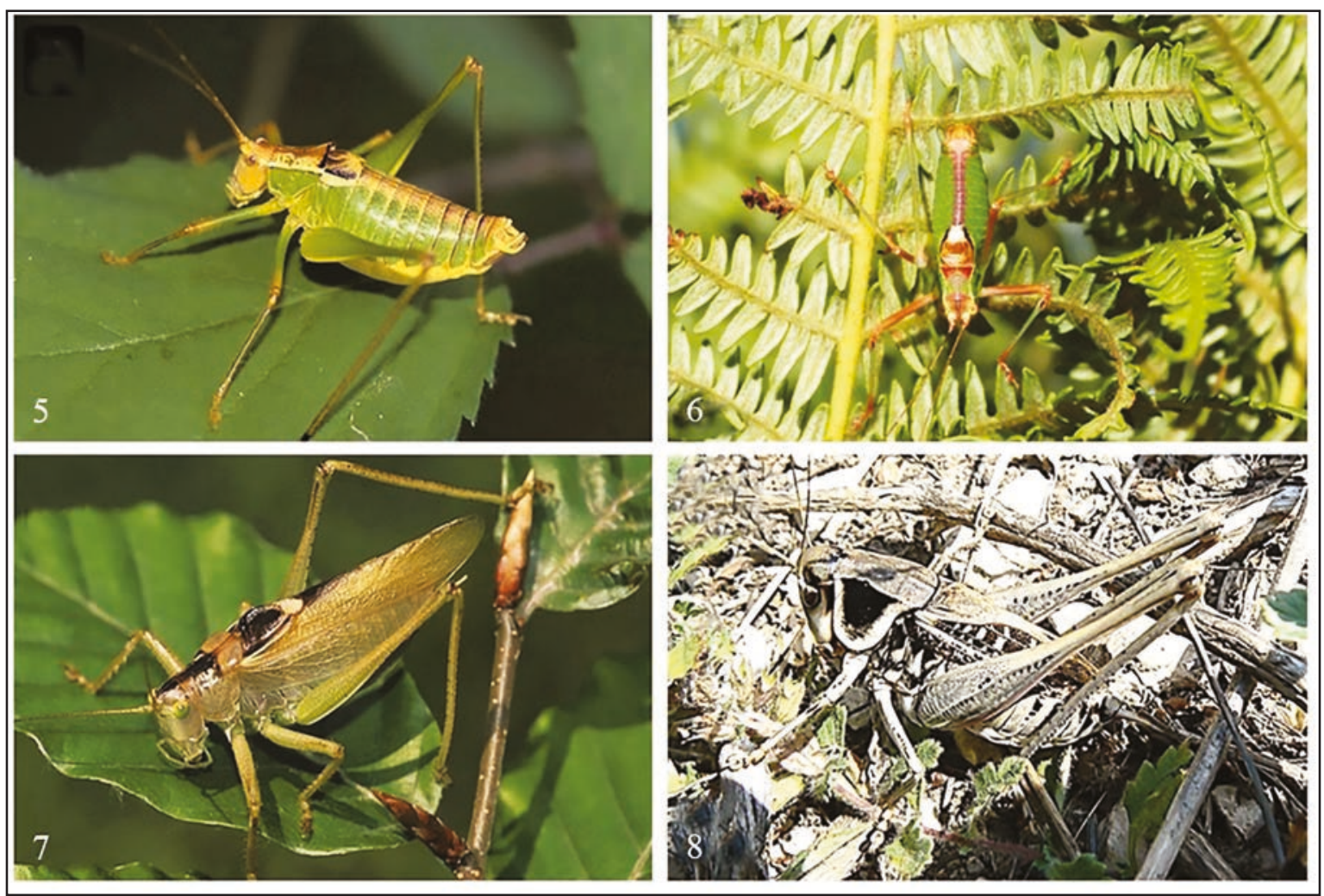

Figure 5. Metaplastes ippolitoi (male), endemic to Calabria and Sicily (photo P. Fontana). Figure 6. Leptophyes sicula (male), endemic to Sicily (photo T. La Mantia). Figure 7. Tettigonia silana (male), endemic to La Sila mountains (Calabria) (photo P. Fontana). Figure 8. Decticus loudoni (male), endemic to Apulia (photo B. Massa).

Pholidoptera aptera goidanichi, Eupholidoptera brunneri, Anonconotus apenninigenus, Anonconotus sibyllinus, Ephippiger carlottae, Ephippiger ruffoi, Ephippiger melisi, Podisma emiliae, Podisma goidanichi, Podisma magadalenae, Podisma ruffoi, Podisma silvestrii, Italopodisma acuminata acuminata, Italopodisma acuminata marsicana, Italopodisma baccettii, Italopodisma costae, Italopodisma ebneri, Italopodisma fiscellana, Italopodisma lagrecai, Italopodisma samnitica, Italopodisma trapezoidalis trapezoidalis, Italopodisma trapezoidalis aprutiana, Italopodisma trapezoidalis curvula, Stenobothrus apenninus, Italohippus albicornis, Italohippus modestus, Italohippus monticola]

High mountains (the Alps, Apennines, and other isolated areas of high elevation) also contribute to the high proportion of endemic species among Italian Orthoptera. In total, the Italian Alps (cf. Figs. 1a, 1b, 1c), harbour 108 species, including 32 endemic taxa (EI: see Table 1). In the Apennines, there are 68 taxa, 35 endemic (EI: see Table 1). The adult phenology of species living at high elevations covers only the period between July and September, with oviposition mainly in August. This short period may explain the remarkable concentration of populations in some places, as well as a noteworthy fluctuation in the density of some species.

The origin of many Alpine and Apennine endemics in Italy is probably the result of Quaternary climatic oscillations, which have led to geographic isolation of species from genera originating from Central Europe in their Italian range, such as Metrioptera, Decticus, Podisma, Chortopodisma, Pseudoprumna, Nadigella, Stenobothrus and Chorthippus. For instance, Alpine and Apennine species of the genus Podisma are well characterized by morphological differences (Fontana \& Pozzebon, 2007).

Barbitistes vicetinus, several Anonconotus species, Pseudoprumna baldensis and Chortopodisma cobellii are also endemic to the Alps. The genus Barbitistes has a Euro-Asiatic distribu- 
tion, ranging from the Caucasus to the Iberian Peninsula. B. vicetinus is a quite common species, which occurs in a restriced area in north-eastern Italy, yet it was first discovered only in 1993. Furthermore, there are also endemic taxa at generic level (Epipodisma, Chortopodisma, Pseudoprumna, Italopodisma and Italohippus).

Restricted to the Apennines, the genus Italohippus is characterized by minor but regular morphological differences that allow the separation of three species from the genus Chorthippus (Fontana \& La Greca, 1999a). Furthermore, C. rubratibialis is an endemic species, replacing C. biguttulus in the Apennines. It occupies all kinds of dry habitats, grasslands, roadside verges, forest clearings, and wasteland. $C$. karelini bruttius (Fontana et La Greca, 1999b), which is distributed in the southern Apennines and is currently considered as a subspecies of a species distributed in central-eastern Europe and Asia, should be considered an old relict taxon deserving of true species status. Stenobothrus apenninus is widespread in the northern and central Apennines, with an isolated southern population on Mount Pollino. This species inhabits alpine meadows in elevations between 1000-2300 m a.s.1. Two Anonconotus species endemic to the Apennines (A. apenninigenus and $A$. sybillinus) are morphologically related to western Alpine taxa, from which they evolved due to geographic isolation during the glacial period. Recurrent glaciations have contributed to a unique mountainous fauna characterized by more widely distributed northern species. In addition, the presence of xerothermic habitats probably favoured the evolution of endemic taxa (Kenyeres et al., 2009).

The tribe Podismini, characterized by brachypterism or apterism, occurs in the Alps and Apennines with many endemic taxa. These are sometimes restricted to single mountain tops and probably originated through Quaternary climatic oscillations. The taxonomic status of some species has to be verified (e.g., the taxonomic status of populations currently recognized as subspecies of Podisma pedestris and Italopodisma trapezoidalis should be revised, as some of these are probably synonymous). However, there is evidence that most of them are endemic taxa. Additionally, uninvestigated high mountain environments could yield further new endemic taxa. Interestingly, the genus Italopodisma is related to the Balkan genus Peripodisma Willemse, 1972, suggesting a Tran- sjonian origin. The latter genus was described from one species from the Pindos Mountain (Greece), $P$. tymphii. Only recently, Lemonnier-Darcemont \& Darcemont (2015a, b) recorded two other species in Albania, P. ceraunii Lemonnier-Darcemont et Darcemont, 2015 and P. llofizii Lemonnier-Darcemont et Darcemont, 2015.

The Apennines also host interesting populations of different species of the genus Decticus: D. aprutianus is a very short-winged species, distributed in the central Apennines and Calabria (with a differentiated population from a bioacoustic point of view), most probably isolated from populations of Decticus loudoni from southern Italy (Apulia). The distribution of $D$. verrucivorus and D. aprutianus may overlap but male stridulation is distinctly different. In the central Apennines, there are populations of very short-winged Decticus species that are clearly different from $D$. aprutianus, but with stridulatory patterns like those of $D$. verrucivorus. The taxonomic status of this populations requires further research. Tettigonia silana is probably related to the Euro-Asiatic T. cantans, from which it is separated on the basis of its song (Ragge \& Reynolds, 1998; Fontana \& Odé, 1999; Heller, 2006; Massa et al., 2012), or even more closely related to T. balcanica Chobanov et LemonnierDarcemont, 2014. T. silana is present in only one area of the Sila Mountains (Calabria) at moderate altitudes.

Chrysochraon beybienkoi is an endemic relict species only known from an area near Lake Ampollino (Calabria). Its closest relative is $C$. dispar, which occurs only in north-eastern regions of Italy.

\section{Endemism in the Italian Peninsula (Apen- nines excluded)}

[Endemic taxa from the Italian Peninsula here considered: Acrometopa italica, Poecilimon superbus, Decticus loudoni, Platycleis romana, Tessellana nigrosignata, Roeseliana brunneri, Zeuneriana marmorata, Pholidoptera littoralis insubrica, Eupholidoptera danconai, Eupholidoptera hesperica, Eupholidoptera magnifica, Rhacocleis japygia, Rhacocleis thyrrhenica, Ephippiger apulus apulus, Ephippiger apulus italicus, Ephippiger cavannai, Ephippiger perforatus, Ephippiger zelleri, Dolichopoda aegilion, Dolichopoda azami ligus- 


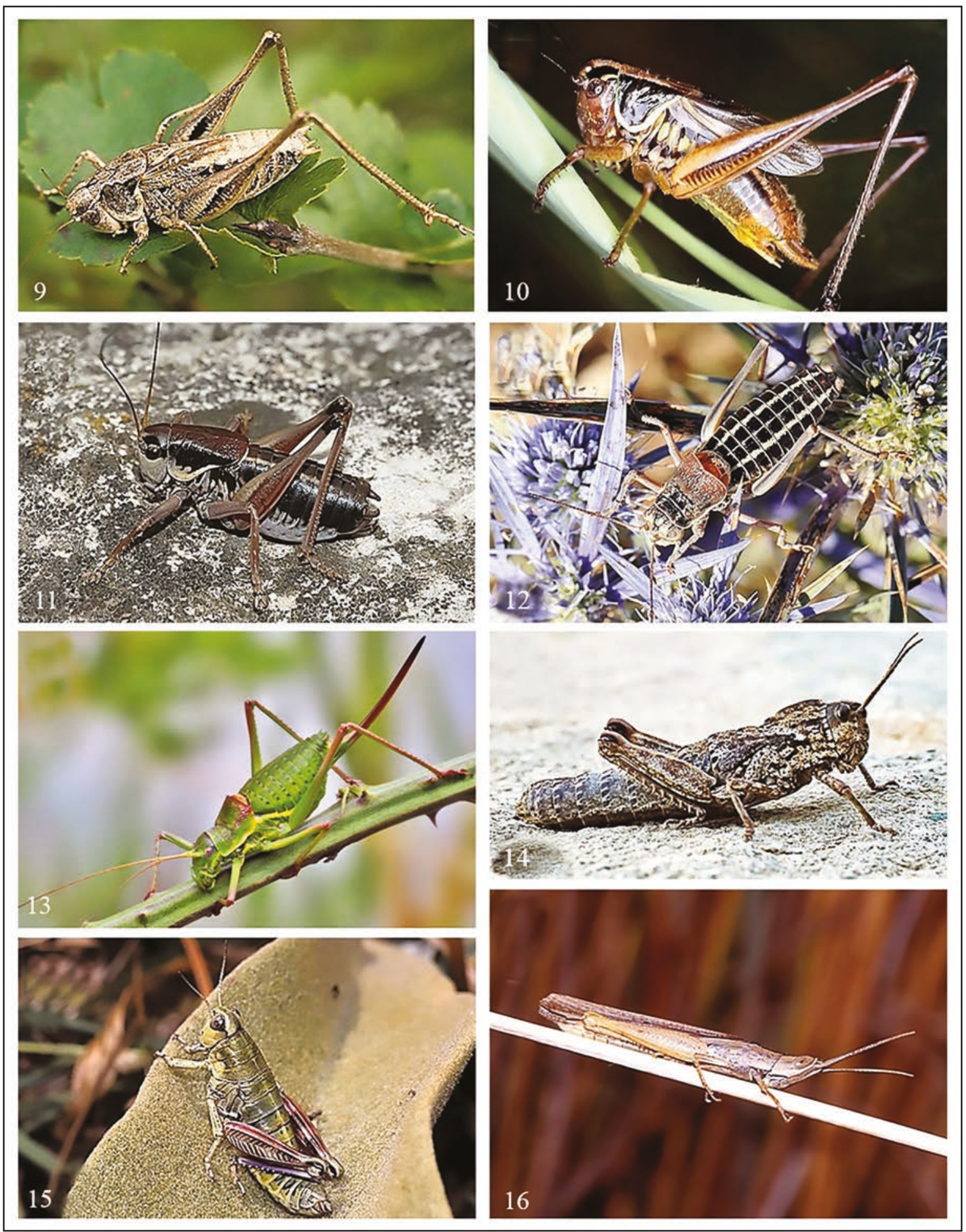

Figure 9. Platycleis concii (male), endemic to calcareous areas of western Sicily. Figure 10. Roeseliana brunneri (male), endemic to Veneto and Friuli. Figure 11. Anonconotus sybillinus (male), endemic to the Apennines. Figure 12. Ephippiger ruffoi (male), endemic to the Apennines (Figs. 9-12 photos P. Fontana). Figure 13. Ephippiger zelleri (female), endemic to central Italy (photo R. Scherini). Figure 14. Acinipe galvagnii (female), endemic to the Egadi islands and western Sicily (photo T. Puma). Figure 15. Italopodisma costae (female), endemic to the Apennines (photo P. Fontana). Figure 16. Ochrilidia sicula (male), endemic to the sand dunes of Sicily, now in decline and endangered (photo B. Massa). 
tica, Dolichopoda azami septentrionalis, Dolichopoda baccettii, Dolichopoda capreensis, Dolichopoda geniculata geniculata, Dolichopoda geniculata pontiana, Dolichopoda laetitiae laetitiae, Dolichopoda laetitiae etrusca, Dolichopoda palpata, Dolichopoda schiavazzii schiavazzii, Dolichopoda schiavazzii caprai, Troglophilus andreinii andreinii, Troglophilus andreinii hydruntinus, Gryllomorpha dalmatina schmidti, Petaloptila andreinii, Petaloptila clauseri, Petaloptila sbordonii, Gryllotalpa octodecim, Gryllotalpa quindecim, Gryllotalpa sedecim, Gryllotalpa viginti, Prionotropis appula, Tropidopola graeca transjonica, Sphingonotus personatus, Omocestus uvarovi, Chorthippus dorsatus garganicus]

At least 45 endemic taxa, within a total number of 188 species, are distributed in non-mountainous areas along the Italian peninsula (EI: see Table 1, cf. also Kleukers et al., 1997; Gomboc \& Segula, 2005; Fanin et al., 2016), where they mostly occur in isolated, arid or semi-arid habitats (e.g., the non endemic genera Acrometopa, Poecilimon, Ephippiger, Eupholidoptera, Rhacocleis, Prionotropis, Oedipoda, Dociostaurus, and Chorthippus).

The genus Ephippiger has a Euro-Asiatic distribution from the Caucasus to the Iberian Peninsula (however, one species is also found in Somalia: Baccetti, 1985). The Italian Peninsula holds six endemic taxa of Ephippiger (in addition to two endemic Apennine taxa). Consequently, it can be assumed that Italy is an important center of evolutionary radiation for these brachypterous orthopterans, with mating systems based on bioacoustical recognition.

Lowland areas in the Italian peninsula may have represented important refuges during the glacial periods. Examples of endemic taxa that remained isolated during Pleistocene glaciations include Prionotropis appula, probably of Transjonian origin, P. willemsorum Massa et Ünal, 2015, which is associated with the Balkan region (Massa et al., 2015); Tropidopola graeca tansjonica, a subspecies endemic to Apulia (the typical subspecies, Tropidopola g. graeca Uvarov, 1926 lives in the Balkan peninsula); Decticus loudoni in South-East Italy (Apulia), which probably evolved from the Balkan populations of $D$. verrucivorus; Oedipoda cynthiae, an endemic species which is probably related to $O$. miniata and currently only known from Apulia (Fontana et al., 2019).
The genus Eupholidoptera has been examined by Allegrucci et al. (2013) who concluded that at least eight endemic taxa occur in Italy. Genetic differences suggest that E. schmidti, which occurs in northern Italy, E. garganica from Apulia (of Transjonian origin, being also present in Greece), and Eupholidoptera hesperica, from southern Italy, are the most differentiated species. By contrast, E. chabrieri is the least genetically differentiated (Allegrucci et al., 2013). These results suggest that the Italian Eupholidoptera comprise species with a very different history of isolation. The brachypterous genus Rhacocleis also shows a high level of endemism, with at least five Italian endemic species; this can be explained by its limited dispersal abilities.

Finally, we would like to include a note on the species-rich genus Chorthippus, probably the most diverse genus occurring in the Mediterranean Basin. The species of this genus are morphologically very similar and often only males can be identified morphologically. Willemse et al. (2009) have highlighted the possibility that some species may hybridize. A case of probable transient hybridization has been described for the pre-Alps by Fontana et al. (2002). In Italy, this genus includes 21 species, some of which are morphologically very similar, being however characterized by different song.

The present climate also depends on the geometry and topography of the Italian peninsula. Climatic differences lead to different environmental conditions, which crucially affect distribution of Italian Orthoptera species. In addition to the strong North-South gradient along the Italian peninsula, Italy is characterized by a strong elevational range. Both contribute to a strong climatic gradient which is responsible for the outstandingly high diversity of flora and fauna. If we exclude the Apennine chain, species richness across the Italian peninsula decreases with increasing elevation. The Italian peninsula is divided into at least two bioclimatic zones: (i) Temperate mid-continental climate (temperate continental/humid continental climate), which includes the Alps, the Po Valley, and the northern part of the Apennines from Liguria to Emilia Romagna; (ii) Mediterranean (temperate with dry, hot summers and mild wet winters), which includes all the area south of the previous zone. Furthermore, the Mediterranean bioclimatic zone is divided into at least two sub-zones: a) Mediterranean-temperate, from the Tuscan-Emilian Apennines to Campania; b) Mediterranean-arid from 
Campania to the southern tips of the peninsula (Pignatti, 1979; Massa, 1982). The latter zone hosts some species typical of arid lands of the Mediterranean that are not found elsewhere in Italy.

\section{CONCLUSIONS}

The total number of species in northern Italy and the Italian peninsula is very similar, but the number of Alpine species is higher than that of Apennine species (109 and 68, respectively). This may be due to the decrease in species richness linked to the 'peninsula effect' generally observed in animal groups (Massa, 1982; Battisti, 2006), but also to a different territory surface (Alps are connected with continental landmass, while Apennines are represented by an isolated dorsal ridge). The importance of the relation between geographic conditions and endemism occurrence has been already highlighted by Anderson
(1994). The situation in the Balkan Mountains is similar to the Italian peninsula. However, the Italian peninsula is surrounded by the Mediterranean sea along its east and west flanks. This strongly limits new colonizations of Orthoptera species. Furthermore, this resulted in a high level of isolation of less mobile species particularly adapted to high elevations. In particular, this applies to Italopodisma and other Podismini, as well as some species of the genus Metrioptera (the Apennine M. caprai may be considered as the ecological substitute of the Alpine $M$. saussuriana), Ephippiger, and others.

Many European species reach their southern distribution limit in northern Italy while a few CentralEuropean species have been able to colonize the Italian peninsula with established populations, and adapt to new habitats. As a consequence of geographic isolation, some of them have evolved into new, endemic taxa (e.g., endemic species and genera living in the Apennines).
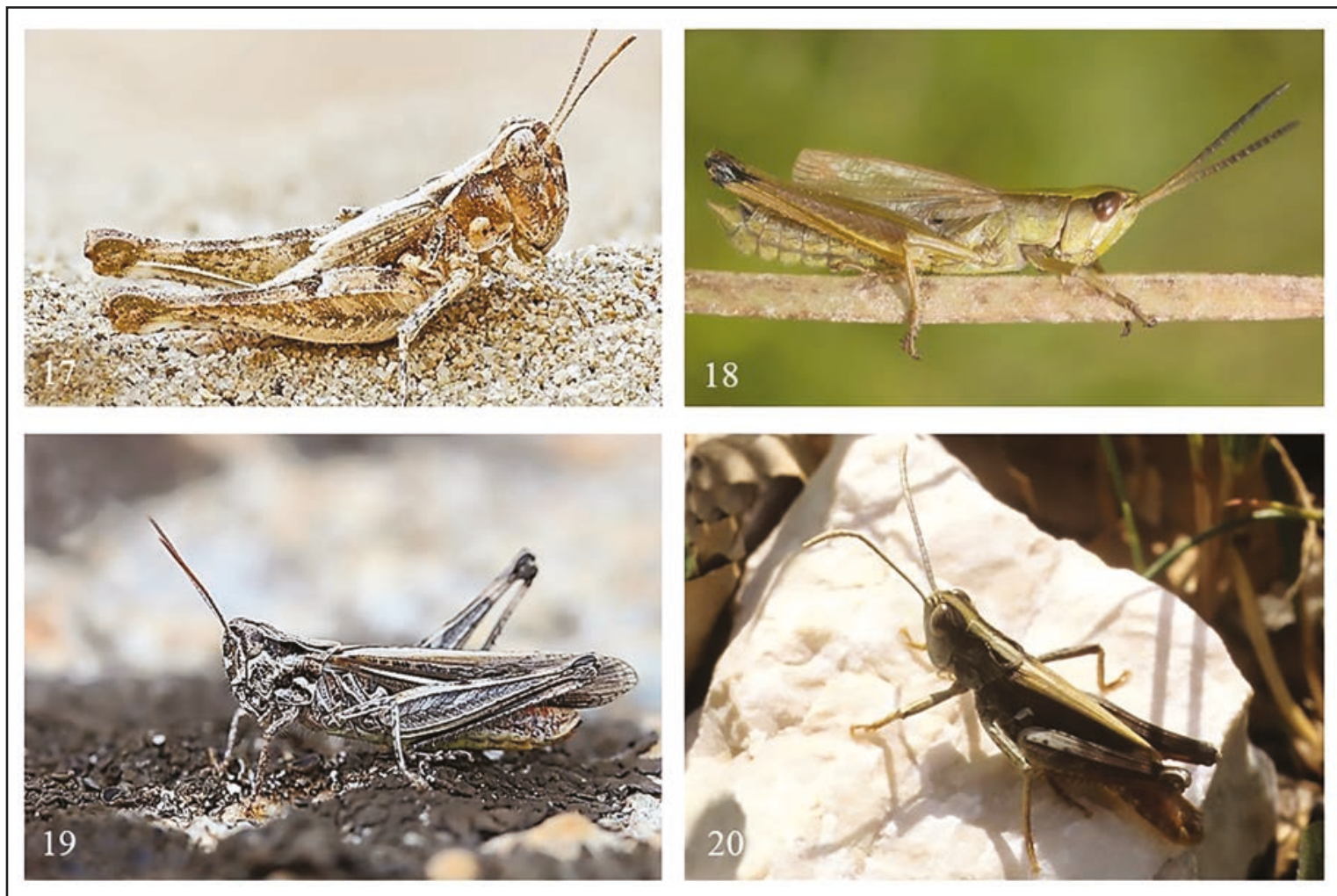

Figure 17. Dociostaurus minutus (male), endemic to the sand dunes of South-East Sicily (photo T. Puma). Figure 18. Chrysochraon beybienkoi (male), endemic to the Ampollino lake (Calabria) (photo P. Fontana). Figure 19. Chorthippus rubratibialis (female), endemic to the Apennines (photo R. Scherini). Figure 20. Italohippus albicornis (male), endemic to the Apennines (photo P. Fontana). 
Due to their ecological isolation, caves acted as micro-refugial centres, favouring the evolution of endemic taxa in the genera Troglophilus (two species in north-eastern Italy and another one in southern Italy: Sbordoni et al., 1981), Dolichopoda (12 species on the Italian peninsula, one in Sardinia: Baccetti \& Capra, 1959, 1970; Di Russo et al., 1994; Casale et al., 2005) and Acroneuroptila (a genus endemic to Sardinia with two species: Baccetti, 1960; Cadeddu, 1970).

The case of Orthoptera is particularly interesting because this insect order comprises species characterized by different ecological traits; e.g., different dispersal abilities, contrasting thermal requirements or specific demands on their habitats characterized by different ecological traits (Table 1). Interestingly, the highest percentage of apterous or micropterous $(35.3 \%)$ and brachypterous $(16.2 \%)$ endemic taxa live in the Apennines, the most isolated mountains of the Italian pensinsula. However, a high percentage of apterous or micropterous $(17.5 \%)$ taxa also occur across the Italian peninsula (Apennines excluded), where they remained isolated at least since the last glacial event (approximately 16-18,000 years ago).

Finally, a millenary human history on the Italian pensinsula historically contributed to an increase in habitat heterogeneity and more recently led to fragmentation of habitats which may have favoured anthropophilous, generalist species. The latter one may cause severe range losses or even extinction among endemic species, due to progressive extinction of stenotopic species. Furthermore, mediterranean lands have been strongly influenced by human activities and thus translocations of species may have occurred during the last centuries. Moreover, there are some species that have high dispersal abilities, which may also be able to expand their ranges. An interesting case of species spreading has been observed during 2016, when a Japanese merchant ship anchored one mile off the coast of Barbate (Andalucia, Spain) between 12th and 25th September was completely invaded by flying Gryllus bimaculatus. These crickets, days after when the ship arrived in Malta, were still alive and some of them were observed mating. Lately the ship left Malta and sailed through the Suez Channel directed to Japan (Luigi Pizzo, pers. comm. to BM). It is then possible some of those crickets have been transferred from Spain to Japan. A similar case of passive transport of the much less common Brachytrupes megacephalus from Sicily to Malta has been reported by Cassar \& Galdies (2018). This allows us to conclude that some species are unsuitable to understand the evolution of regional Orthoptera faunas while endemics, generally consisting of a few small populations, are the well-suited indicators to understand biogeographical patterns.

Considering conservation status of the Italian endemic Orthoptera, out of 136 species included in the European list (subspecies were not considered in the European Red List), 66 are Least Concern, 12 Near Threatened, 16 Vulnerable, 27 Endangered, and 16 Critically Endangered. In total, this accounts for 59 species $(43.4 \%)$ which may suffer future declines. Among the 29 species endemic to the Apennines included in the European Red List, 6 are Least Concern, 4 Vulnerable, 12 Endangered, and 7 Critically Endangered (Table 2; Appendix 1).

\begin{tabular}{|c|c|c|c|c|c|}
\hline & $\begin{array}{c}\text { Least } \\
\text { Concern }\end{array}$ & $\begin{array}{c}\text { Near } \\
\text { Threatened }\end{array}$ & Vulnerable & Endangered & $\begin{array}{c}\text { Critically } \\
\text { Endangered }\end{array}$ \\
\hline Tettigoniidae & 27 & 9 & 6 & 9 & 7 \\
\hline Rhaphidophoridae & 10 & & 4 & & \\
\hline $\begin{array}{c}\text { Gryllidae + } \\
\text { Gryllotalpidae }\end{array}$ & 4 & & 3 & & \\
\hline Pamphagidae & 4 & 2 & & & \\
\hline Acrididae & 21 & 1 & 3 & 18 & 8 \\
\hline Total (136) & $66(48.5 \%)$ & $12(8.8 \%)$ & $16(11.8 \%)$ & $27(19.8 \%)$ & $15(11.0 \%)$ \\
\hline
\end{tabular}

Table 2. Number and percentage (in parenthesis) of the Italian endemic species included in different categories of conservation concern for each family of Italian Orthoptera. The percentage refers to the total number of Italian endemic species included in the European Red List. Source: Hochkirch et al. (2016). 


\section{APPENDIX 1}

List of species and subspecies among Italian Orthoptera, their distribution in Italy, and their Red List status. Abbreviations. $\mathrm{E}=$ endemic. Red List (according to Hochkirch et al., 2016): $\mathrm{CR}=$ Critically Endangered; $\mathrm{EN}=$ Endangered; $\mathrm{VU}=$ Vulnerable; $\mathrm{NT}=$ Near Threatened; $\mathrm{LC}=$ Least Concern; DD = Data Deficient; $\mathrm{NA}=$ Not available. In bold: endemic taxa.

\begin{tabular}{|c|c|c|c|c|}
\hline & Family/species & $\begin{array}{l}\text { Red } \\
\text { List }\end{array}$ & $\begin{array}{l}\text { Endemic } \\
\text { taxa }(E)\end{array}$ & Distribution \\
\hline \multicolumn{5}{|c|}{ Tettigonidae } \\
\hline 1 & Phaneroptera falcata (Poda, 1761) & LC & & North and Gargano, Apulia \\
\hline 2 & Phaneroptera nana Fieber, 1853 & LC & & Italian peninsula, Sicily, and Sardinia \\
\hline 2 & Tylopsis lilifolia (Fabricius, 1793) & LC & & Italian peninsula, Sicily, and Sardinia \\
\hline 4 & Acrometopa italica Ramme, 1927 & $\mathrm{LC}$ & $\mathrm{E}$ & Italian peninsula, Sicily, and Sardinia \\
\hline 5 & Acrometopa macropoda (Burmeister, 1838) & LC & & From Friuli Venezia Giulia to Apulia \\
\hline 6 & Isophya modestior Brunner, 1882 & $\mathrm{LC}$ & & Friuli, Veneto, Trentino, and Lombardy \\
\hline 7 & Barbitistes alpimus Fruhstorfer, 1920 & LC & & Alps and north Apennines \\
\hline 8 & Barbitistes fischeri (Yersin, 1854) & $\mathrm{LC}$ & & Parco Naz. Gran Paradiso, Piedmont \\
\hline 9 & Barbitistes ocskayi Charpentier, 1850 & LC & & Carso, Friuli Venezia Giulia \\
\hline 10 & Barbitistes serricauda (Fabricius, 1794) & $\mathrm{LC}$ & & North-east Italy and north Apennines \\
\hline 11 & $\begin{array}{l}\text { Barbitistes vicetinus Galvagni et Fontana, } \\
1993\end{array}$ & NT & $\mathrm{E}$ & Veneto and Trentino \\
\hline 12 & Barbitistes yersini Brunner, 1878 & LC & & Friuli Venezia Giulia and Abruzzo \\
\hline 13 & Metaplastes ippolitoi La Greca, 1948 & LC & $\mathrm{E}$ & Calabria and Sicily \\
\hline 14 & Metaplastes pulchripennis (A. Costa, 1863) & LC & & Italian peninsula and Sicily \\
\hline 15 & Andreiniimon muptialis (Karny, 1918) & VU & & Carso Triestino, Umbria and Marche \\
\hline 16 & Leptophyes albovittata (Kollar, 1833) & LC & & Trentino Alto Adige \\
\hline 17 & Leptophyes boscii Fieber, 1853 & LC & & Alps and north Apennines \\
\hline 18 & $\begin{array}{l}\text { Leptophyes calabra Kleukers, Odé et } \\
\text { Fontana, } 2010\end{array}$ & CR & E & Calabria \\
\hline 19 & Leptophyes laticauda (Frivaldsky, 1867) & LC & & Italian peninsula \\
\hline 20 & Leptophyes punctatissima (Bosc, 1792) & $\mathrm{LC}$ & & Italian peninsula and Sardinia \\
\hline 21 & $\begin{array}{l}\text { Leptophyes sicula Kleukers, Odé et } \\
\text { Fontana, } 2010\end{array}$ & LC & $\mathrm{E}$ & Sicily \\
\hline 22 & Odontura arcuata Messina, 1981 & LC & E & Sicily \\
\hline 23 & Odontura borrei Bolívar, 1878 & LC & & Is. of Lampedusa (Sicily) \\
\hline 24 & Odontura calaritana A. Costa, 1883 & LC & E & Sardinia \\
\hline 25 & Odontura stenoxypha (Fieber, 1853) & LC & & Sicily \\
\hline
\end{tabular}




\begin{tabular}{|c|c|c|c|c|}
\hline 26 & Poecilimon elegans Brunner, 1878 & LC & & North-east Italy \\
\hline 27 & Poecilimon laevissimus (Fischer, 1854) & LC & & Sicily \\
\hline 28 & Poecilimon ornatus (Schmidt, 1850) & LC & & North-east Italy \\
\hline 29 & Poecilimon superbus (Fischer, 1854) & LC & $\mathrm{E}$ & Italian peninsula \\
\hline 30 & Poecilimon thoracicus (Fieber, 1853) & LC & & Carso Goriziano (Friuli Venezia Giulia) \\
\hline 31 & Polysarcus denticauda (Charpentier, 1825) & LC & & Alps and central-north Apennines \\
\hline 32 & Meconema meridionale A. Costa, 1860 & LC & & Italian peninsula and Sicily \\
\hline 33 & Meconema thalassimum (De Geer, 1773) & LC & & Italian peninsula \\
\hline 34 & Cyrtaspis scutata (Charpentier, 1825) & LC & & Italian peninsula, Sicily, and Sardinia \\
\hline 35 & $\begin{array}{l}\text { Conocephalus (Conocephalus) } \\
\text { conocephalus (Linnaeus, 1767) }\end{array}$ & LC & & Italian peninsula, Sicily, and Sardinia \\
\hline 36 & $\begin{array}{l}\text { Conocephalus (Anisoptera) d. dorsalis } \\
\text { (Latreille, 1804) }\end{array}$ & LC & & Central-north Italy \\
\hline 37 & $\begin{array}{l}\text { Conocephalus (Anisoptera) fuscus } \\
\text { (Fabricius, 1793) }\end{array}$ & LC & & Italian peninsula, Sicily, and Sardinia \\
\hline 38 & Ruspolia nitidula (Scopoli, 1786) & LC & & Italian peninsula, Sicily, and Sardinia \\
\hline 39 & Tettigonia cantans (Fuessly, 1775) & LC & & Italian peninsula and Sardinia \\
\hline 40 & $\begin{array}{l}\text { Tettigonia caudata caudata (Charpentier, } \\
1854 \text { ) }\end{array}$ & LC & & North-east Italy \\
\hline 41 & Tettigonia longispina Ingrisch, 1983 & $\mathrm{CR}$ & $\mathrm{E}$ & Sardinia \\
\hline 42 & Tettigonia silana Capra, 1936 & DD & $\mathrm{E}$ & Calabria \\
\hline 43 & Tettigonia viridissima (Linnaeus, 1758) & LC & & Italian peninsula, Sicily, and Sardinia \\
\hline 44 & Decticus albifrons (Fabricius, 1775) & LC & & Italian peninsula, Sicily, and Sardinia \\
\hline 45 & Decticus aprutianus Capra, 1936 & LC & $\mathrm{E}$ & Apennines \\
\hline 46 & Decticus loudoni Ramme, 1933 & VU & $E$ & Apulia \\
\hline 47 & Decticus v, verrucivorus (Linnaeus, 1758) & LC & & Central-north Italy, Sardinia? \\
\hline 48 & Platycleis a. affinis Fieber, 1853 & LC & & Italian peninsula and Sicily \\
\hline 49 & Platycleis a. albopunctata (Goeze, 1778) & LC & & North-west Italy \\
\hline 50 & Platycleis concii Galvagni, 1959 & LC & $\mathrm{E}$ & Sicily \\
\hline 51 & Platycleis e. escalerai Bolívar, 1899 & LC & & Central-south Italy \\
\hline 52 & Platycleis falx laticauda Brunner, 1882 & VU & & South Italy and Sicily \\
\hline 53 & Platycleis grisea grisea (Fabricius, 1781) & LC & & Italian peninsula, Sicily, and Sardinia \\
\hline 54 & Platycleis i. intermedia (Serville, 1839) & LC & & Italian peninsula, Sicily, and Sardinia \\
\hline 55 & Platycleis ragusai Ramme, 1927 & LC & $\mathrm{E}$ & Sicily \\
\hline
\end{tabular}




\begin{tabular}{|c|c|c|c|c|}
\hline 56 & Platycleis romana Ramme, 1927 & LC & & Italian peninsula \\
\hline 57 & Platycleis sabulosa Azam, 1901 & LC & & South Italy, Sicily, and Sardinia \\
\hline 58 & $\begin{array}{l}\text { Sardoplatycleis galvagnii (Fontana, } \\
\text { Buzzetti et Odé, 2010) }\end{array}$ & $\mathrm{CR}$ & $\mathrm{E}$ & Sardinia \\
\hline 59 & Tessellana lagrecai Messina, 1978 & VU & $\mathrm{E}$ & Sicily \\
\hline 60 & Tessellana nigrosignata (A. Costa, 1863) & EN & $\mathrm{E}$ & South Italy \\
\hline 61 & Tessellana t. tessellata (Charpentier, 1825) & LC & & Italian peninsula, Sicily, and Sardinia \\
\hline 62 & $\begin{array}{l}\text { Incertana drepanensis (Massa, Fontana et } \\
\text { Buzzetti, 2006) }\end{array}$ & $\mathrm{CR}$ & $\mathrm{E}$ & Sicily \\
\hline 63 & Montana m. montana (Kollar, 1833) & LC & & North Italy \\
\hline 64 & Montana stricta (Zeller, 1849) & LC & & Italian peninsula \\
\hline 65 & Metrioptera brachyptera (Linnaeus, 1761) & LC & & North-east Italy \\
\hline 66 & Metrioptera caprai caprai Baccetti, 1956 & VU & $E$ & Central Apennines \\
\hline 67 & $\begin{array}{l}\text { Metrioptera caprai baccettii Galvagni, } \\
1958\end{array}$ & VU & $\mathrm{E}$ & Central Apennines \\
\hline 68 & $\begin{array}{l}\text { Metrioptera caprai galvagnii Baccetti, } \\
1963\end{array}$ & VU & $\mathrm{E}$ & North Apennines \\
\hline 69 & Metrioptera caprai lagrecai Baccetti, 1958 & VU & $\mathrm{E}$ & Central Apennines \\
\hline 70 & $\begin{array}{l}\text { Metrioptera s. saussuriana (Frey-Gessner, } \\
\text { 1872) }\end{array}$ & LC & & North-west Italy \\
\hline 71 & Bicolorana b. bicolor (Philippi, 1830) & $\mathrm{LC}$ & & Italian peninsula \\
\hline 72 & Bicolorana kraussi (Padewieth, 1900) & NT & & Friuli Venezia Giulia \\
\hline 73 & Roeseliana minor Nadig, 1961 & LC & & $\begin{array}{l}\text { Lombardy, Emilia-Romagna, Piedmont, } \\
\text { Liguria, Marche, Tuscany; Switzerland }\end{array}$ \\
\hline 74 & Roeseliana brunneri Ramme, 1951 & NT & $\mathrm{E}$ & Venetian lagoon \\
\hline 75 & Roeseliana roeselii (Hagenbach, 1822) & $\mathrm{LC}$ & & North-east Italy \\
\hline 76 & Zeuneriana abbreviata (Serville, 1839) & LC & & North-west Italy \\
\hline 77 & Zeuneriana marmorata (Fieber, 1853) & EN & & North-east Italy \\
\hline 78 & Sepiana sepium (Yersin, 1854) & LC & & Italian peninsula, Sicily, and Sardinia \\
\hline 79 & Modestana modesta (Fieber, 1853) & LC & & North-east Italy \\
\hline 80 & Pholidoptera a. aptera (Fabricius, 1793) & $\mathrm{LC}$ & & Alps \\
\hline 81 & $\begin{array}{l}\text { Pholidoptera aptera goidanichi Baccetti, } \\
1963\end{array}$ & LC & $\mathrm{E}$ & Central-north Apennines \\
\hline 82 & Pholidoptera d. dalmatica (Krauss, 1899) & $\mathrm{LC}$ & & North-east Italy \\
\hline 83 & Pholidoptera fallax (Fischer, 1854) & LC & & Italian peninsula, Sicily, and Sardinia \\
\hline
\end{tabular}




\begin{tabular}{|c|c|c|c|c|}
\hline 84 & Pholidoptera femorata (Fieber, 1853) & LC & & Italian peninsula, Sicily, and Sardinia \\
\hline 85 & Pholidoptera griseoaptera (De Geer, 1773) & LC & & Italian peninsula and Sardinia \\
\hline 86 & Pholidoptera l. littoralis (Fieber, 1853) & LC & & North-east Italy \\
\hline 87 & $\begin{array}{l}\text { Pholidoptera littoralis insubrica Nadig, } \\
1961\end{array}$ & LC & $\mathrm{E}$ & North-west Alps \\
\hline 88 & $\begin{array}{l}\text { Eupholidoptera bimucronata (Ramme, } \\
\text { 1927) }\end{array}$ & LC & $\mathrm{E}$ & Sicily \\
\hline 89 & $\begin{array}{l}\text { Eupholidoptera chabrieri (Charpentier, } \\
1825 \text { ) }\end{array}$ & LC & & North-west Italy \\
\hline 90 & $\begin{array}{l}\text { Eupholidoptera } \\
\text { Tozzetti, 1881) }\end{array}$ brunneri $\quad$ (Targioni & LC & $\mathrm{E}$ & Central Apennine \\
\hline 91 & Eupholidoptera danconai La Greca, 1959 & NT & $\mathrm{E}$ & Italian peninsula \\
\hline 92 & Eupholidoptera garganica La Greca, 1959 & NT & & Apulia \\
\hline 93 & Eupholidoptera hesperica La Greca, 1959 & LC & $\mathrm{E}$ & South Italy \\
\hline 94 & $\begin{array}{l}\text { Eupholidoptera magnifica (A. Costa, } \\
\text { 1863) }\end{array}$ & LC & $\mathrm{E}$ & Italian peninsula and Sardinia \\
\hline 95 & Eupholidoptera schmidti (Fieber, 1861) & LC & & Central and north-east Italy \\
\hline 96 & Anonconotus alpinus (Yersin, 1858) & LC & $\mathrm{E}$ & North-west Alps \\
\hline 97 & $\begin{array}{l}\text { Anonconotus apenninigenus } \text { Targioni } \\
\text { Tozzetti, } 1881\end{array}$ & $\mathrm{CR}$ & $\mathrm{E}$ & North Apennines \\
\hline 98 & Anonconotus baracunensis Nadig, 1987 & NT & $\mathrm{E}$ & North-west Alps \\
\hline 99 & Anonconotus ghilianii Camerano, 1878 & LC & $\mathrm{E}$ & North-west Alps \\
\hline 100 & Anonconotus italoaustriacus Nadig, 1987 & EN & $\mathrm{E}$ & North-east Alps \\
\hline 101 & Anonconotus ligustinus Galvagni, 2002 & EN & $\mathrm{E}$ & North-west Alps \\
\hline 102 & $\begin{array}{l}\text { Anonconotus occidentalis Carron et } \\
\text { Wermeille, } 2002\end{array}$ & LC & $\mathrm{E}$ & North-west Alps \\
\hline 103 & $\begin{array}{l}\text { Anonconotus pusillus Carron et Sardet, } \\
2002\end{array}$ & NT & $\mathrm{E}$ & North-west Alps \\
\hline 104 & Anonconotus sibyllinus Galvagni, 2002 & $\mathrm{EN}$ & $\mathrm{E}$ & Central Apennines \\
\hline 105 & Yersinella beybienkoi La Greca, 1974 & LC & & Italian peninsula \\
\hline 106 & Yersinella raymondi (Yersin, 1860) & $\mathrm{LC}$ & & Italian peninsula, Sicily, and Sardinia \\
\hline 107 & Pachytrachis gracilis (Brunner, 1861) & LC & & North-east Italy \\
\hline 108 & Pachytrachis striolatus (Fieber, 1853) & LC & & North and north-east Italy \\
\hline 109 & $\begin{array}{l}\text { Pterolepis elymica Galvagni et Massa, } \\
1979\end{array}$ & EN & $\mathrm{E}$ & Sicily \\
\hline 110 & Pterolepis pedata A. Costa, 1882 & LC & & Sardinia and island of Lampedusa \\
\hline
\end{tabular}




\begin{tabular}{|c|c|c|c|c|}
\hline 111 & Rhacocleis annulata Fieber, 1853 & LC & & Central-south Italy, Sicily, and Sardinia \\
\hline 112 & Rhacocleis baccettii Galvagni, 1976 & NT & $\mathrm{E}$ & Sardinia \\
\hline 113 & Rhacocleis corsicana Bonfils, 1960 & NT & & Sardinia and Corsica \\
\hline 114 & Rhacocleis japygia La Greca, 1959 & EN & $E$ & South Italy \\
\hline 115 & $\begin{array}{l}\text { Rhacocleis germanica (Herrich-Schaeffer, } \\
\text { 1840) }\end{array}$ & LC & & Italian peninsula \\
\hline 116 & Rhacocleis maculipedes (Ingrisch, 1983) & EN & $\mathrm{E}$ & Sardinia \\
\hline 117 & Rhacocleis n. neglecta (A. Costa, 1863) & LC & & Italian peninsula and Sicily \\
\hline 118 & Rhacocleis thyrrhenica La Greca, 1952 & NT & $\mathrm{E}$ & Tyrrhenian islands of central Italy \\
\hline 119 & $\begin{array}{llll}\text { Ctenodecticus } & \text { b. } & \text { bolivari Targioni } \\
\text { Tozzetti, } 1881 & & & \end{array}$ & LC & $E$ & Sardinia \\
\hline 120 & Ctenodecticus siculus Ramme, 1927 & LC & $\mathrm{E}$ & Sicily \\
\hline 121 & Antaxius difformis (Brunner, 1861) & LC & & North Italy \\
\hline 122 & Chopardius p. pedestris (Fabricius, 1787) & LC & & North Italy \\
\hline 123 & $\begin{array}{l}\text { Chopardius pedestris apuanus (Nadig, } \\
\text { 1958) }\end{array}$ & LC & $\mathrm{E}$ & Apuane Alps \\
\hline 124 & Saga pedo (Pallas, 1771) & LC & & Italian peninsula, Sicily, and Sardinia \\
\hline 125 & Ephippiger a. apulus (Ramme, 1933) & LC & $\mathrm{E}$ & South Italy \\
\hline 126 & $\begin{array}{l}\text { Ephippiger apulus italicus La Greca, } \\
1959\end{array}$ & LC & $\mathrm{E}$ & South Italy \\
\hline 127 & $\begin{array}{l}\text { Ephippiger cavannai (Targioni Tozzetti, } \\
\text { 1881) }\end{array}$ & LC & $\mathrm{E}$ & South Italy \\
\hline 128 & Ephippiger perforatus Rossi, 1790 & LC & $\mathrm{E}$ & Italian peninsula \\
\hline 129 & $\begin{array}{l}\text { Ephippiger camillae Fintana et Massa, } \\
2000\end{array}$ & $\mathrm{CR}$ & $\mathrm{E}$ & Sicily \\
\hline 130 & $\begin{array}{l}\text { Ephippiger carlottae Fontana et Odé, } \\
2003\end{array}$ & NT & $\mathrm{E}$ & North Apennines \\
\hline 131 & Ephippiger discoidalis (Fieber, 1853) & LC & & North-east Italy \\
\hline 132 & Ephippiger persicarius Fruhstorfer, 1921 & LC & $\mathrm{E}$ & North Italy \\
\hline 133 & $\begin{array}{l}\text { Ephippiger terrestris bormansi Brunner, } \\
1882\end{array}$ & LC & $\mathrm{E}$ & North-west Italy \\
\hline 134 & Ephippiger terrestris caprai Nadig, 1980 & LC & $\mathrm{E}$ & North-west Italy \\
\hline 135 & Ephippiger melisi Baccetti, 1958 & EN & $\mathrm{E}$ & Central Apennines \\
\hline 136 & Ephippiger ruffoi Galvagni, 1955 & EN & $\mathrm{E}$ & Central Apennines \\
\hline 137 & Ephippiger zelleri (Fischer, 1854) & EN & $\mathrm{E}$ & Central Italy \\
\hline 138 & Lucasinova nigromarginata (Lucas, 1849) & LC & & Sicily \\
\hline
\end{tabular}




\begin{tabular}{|c|c|c|c|c|}
\hline 139 & Uromenus annae (Targioni Tozzetti, 1881) & NT & $\mathrm{E}$ & Sardinia \\
\hline 140 & Uromenus b. bonneti (Bolívar, 1907) & LC & & Is. of Lampedusa (Sicily) \\
\hline 141 & Uromenus bonneti painoi Ramme, 1927 & LC & $\mathrm{E}$ & Sicily \\
\hline 142 & $\begin{array}{l}\text { Uromenus brevicollis insularis (Chopard, } \\
\text { 1923) }\end{array}$ & LC & $\mathrm{E}$ & Sardinia and Corsica \\
\hline 143 & $\begin{array}{l}\text { Uromenus brevicollis trinacriae (La } \\
\text { Greca, 1964) }\end{array}$ & LC & $\mathrm{E}$ & Sicily \\
\hline 144 & Uromenus elegans (Fischer, 1853) & LC & & Italian peninsula \\
\hline 145 & Uromenus riggioi La Greca, 1964 & $\mathrm{CR}$ & $\mathrm{E}$ & Sicily \\
\hline 146 & Uromenus siculus (Fieber, 1853) & LC & $\mathrm{E}$ & Sicily \\
\hline 147 & Praephippigera pachygaster (Lucas, 1849) & DD & & Sardinia and North Africa \\
\hline \multicolumn{5}{|c|}{ Rhaphidophoridae } \\
\hline 148 & Dolichopoda aegilion Baccetti, 1975 & VU & $\mathrm{E}$ & Tuscan Archipelago \\
\hline 149 & $\begin{array}{l}\text { Dolichopoda azami ligustica Baccetti et } \\
\text { Capra, } 1958\end{array}$ & LC & $\mathrm{E}$ & Central and north Italy \\
\hline 150 & $\begin{array}{l}\text { Dolichopoda azami } \\
\text { Baccetti et Capra, } 1959\end{array}$ & LC & $\mathrm{E}$ & Tuscany \\
\hline 151 & Dolichopoda baccettii Capra, 1957 & VU & $\mathrm{E}$ & Mt. Argentario, Tuscany \\
\hline 152 & Dolichopoda capreensis Capra, 1968 & VU & $\mathrm{E}$ & Capri Is., Campania \\
\hline 153 & $\begin{array}{l}\text { Dolichopoda g. geniculata (O.G. Costa, } \\
\text { 1860) }\end{array}$ & $\mathrm{LC}$ & $\mathrm{E}$ & South Italy \\
\hline 154 & $\begin{array}{l}\text { Dolichopoda geniculata pontiana Capra, } \\
1967\end{array}$ & LC & $\mathrm{E}$ & Ponziane Is., Latium \\
\hline 155 & Dolichopoda l. laetitiae Minozzi, 1920 & LC & $\mathrm{E}$ & Central Italy \\
\hline 156 & $\begin{array}{l}\text { Dolichopoda laetitiae etrusca } \text { Baccetti et } \\
\text { Capra, } 1959\end{array}$ & LC & $\mathrm{E}$ & Central Italy \\
\hline 157 & $\begin{array}{l}\text { Dolichopoda muceddai Rampini et Di } \\
\text { Russo, } 2005\end{array}$ & VU & $\mathrm{E}$ & Sardinia \\
\hline 158 & Dolichopoda palpata (Sulzer, 1776) & $\mathrm{DD}$ & $\mathrm{E}$ & Calabria and Sicily \\
\hline 159 & Dolichopoda s. schiavazzii Capra, 1934 & LC & $\mathrm{E}$ & Tuscan coast \\
\hline 160 & $\begin{array}{l}\text { Dolichopoda schiavazzii caprai Lanza, } \\
1954\end{array}$ & $\mathrm{LC}$ & $E$ & Tuscany \\
\hline 161 & $\begin{array}{l}\text { Troglophilus (Troglophilus) a. andreinii } \\
\text { Capra, } 1927\end{array}$ & LC & $\mathrm{E}$ & South Italy \\
\hline 162 & $\begin{array}{l}\text { Troglophilus (Troglophilus) andreinii } \\
\text { hydruntinus La Greca, } 1961\end{array}$ & LC & $\mathrm{E}$ & Apulia \\
\hline 163 & $\begin{array}{lll}\begin{array}{l}\text { Troglophilus } \\
\text { (Kollar, 1833) }\end{array} & \text { (Troglophilus) } & \text { cavicola } \\
& & \end{array}$ & LC & & North-east Italy \\
\hline
\end{tabular}




\begin{tabular}{|c|c|c|c|c|}
\hline 164 & $\begin{array}{l}\text { Troglophilus (Paratroglophilus) } n . \\
\text { neglectus Krauus, } 1879\end{array}$ & LC & & North-east Italy \\
\hline 165 & $\begin{array}{l}\text { Diestrammena (Tachycines) asynamora } \\
\text { (Adelung, 1902) }\end{array}$ & NA & & Italian peninsula and Sicily (introduced) \\
\hline \multicolumn{5}{|c|}{ Gryllidae } \\
\hline 166 & Nemobius s. sylvestris (Bosc, 1792) & LC & & Central-north Italy, Sardinia \\
\hline 167 & Pteronemobius h. heydenii (Fischer, 1853) & LC & & Italian peninsula, Sicily, and Sardinia \\
\hline 168 & Pteronemobius lineolatus (Brullé, 1835) & LC & & North-west Italy \\
\hline 169 & Stenonemobius gracilis (Jakovleff, 1871) & DD & & Italian peninsula and Sicily \\
\hline 170 & Trigonidium cicindeloides Rambur, 1839 & LC & & Italian peninsula, Sicily, and Sardinia \\
\hline 171 & Natula averni (A. Costa, 1855) & VU & & Italian peninsula, Sicily, and Sardinia \\
\hline 172 & Gryllomorpha d. dalmatina (Ocskay, 1832) & LC & & Italian peninsula, Sicily, and Sardinia \\
\hline 173 & $\begin{array}{l}\text { Gryllomorpha dalmatina schmidti } \\
\text { Gorochov, } 1996\end{array}$ & LC & $\mathrm{E}$ & Latium \\
\hline 174 & Gryllomorphella uclensis (Pantel, 1890) & LC & & Italian peninsula, Sicily, and Sardinia \\
\hline 175 & $\begin{array}{l}\text { Petaloptila (Italoptila) andreinii Capra, } \\
1937\end{array}$ & LC & $\mathrm{E}$ & Italian peninsula \\
\hline 176 & $\begin{array}{l}\text { Petaloptila (Petaloptila) clauseri } \\
\text { (Schmidt, 1991) }\end{array}$ & DD & $\mathrm{E}$ & North Italy \\
\hline 177 & $\begin{array}{l}\text { Petaloptila (Petaloptila) sbordonii } \\
\text { (Baccetti, 1979) }\end{array}$ & DD & $\mathrm{E}$ & Calabria \\
\hline 178 & Acroneuroptila puddui Cadeddu, 1970 & VU & $\mathrm{E}$ & Sardinia \\
\hline 179 & Acroneuroptila sardoa Baccetti, 1960 & VU & $\mathrm{E}$ & Sardinia \\
\hline 180 & Gryllus bimaculatus De Geer, 1773 & LC & & Italian peninsula, Sicily, and Sardinia \\
\hline 181 & Gryllus campestris Linnaeus, 1758 & LC & & Italian peninsula, Sicily, and Sardinia \\
\hline 182 & $\begin{array}{l}\text { Brachytrupes megacephalus (Lefèvre, } \\
\text { 1827) }\end{array}$ & VU & & Sicily and Sardinia \\
\hline 183 & Melanogryllus $d$. desertus (Pallas, 1771) & LC & & Italian peninsula and Sicily \\
\hline 184 & Acheta domesticus (Linnaeus, 1758) & LC & & Italian peninsula, Sicily, and Sardinia \\
\hline 185 & Acheta gossypii O.G. Costa, 1855 & $\mathrm{DD}$ & & Apulia \\
\hline 186 & Acheta hispanicus Rambur, 1839 & LC & & South Italy and Sicily \\
\hline 187 & Modicogryllus a. algirius (Saussure, 1877) & LC & & Sicily \\
\hline 188 & Svercus p. palmetorum (Krauss, 1902) & NT & & Calabria, Sicily, and Sardinia \\
\hline 189 & $\begin{array}{l}\text { Eumodicogryllus b. bordigalensis } \\
\text { (Latreille, 1804) }\end{array}$ & LC & & Italian peninsula, Sicily, and Sardinia \\
\hline 190 & Grylloderes brunneri (Riggio, 1888) & NT & & Sicily \\
\hline
\end{tabular}




\begin{tabular}{|c|c|c|c|c|}
\hline 191 & Oecanthus dulcisonans Gorochov, 1993 & LC & & Italian peninsula, Sicily, and Sardinia \\
\hline 192 & Oecanthus p. pellucens (Scopoli, 1763) & LC & & Italian peninsula, Sicily, and Sardinia \\
\hline \multicolumn{5}{|c|}{ Mogoplistidae } \\
\hline 193 & Mogoplistes brunneus Serville, 1839 & LC & & Italian peninsula, Sicily, and Sardinia \\
\hline 194 & Paramogoplistes novaki (Krauss, 1888) & DD & & $\begin{array}{l}\text { few localities in Sardinia and on the } \\
\text { Tyrrhenian coast of Italy }\end{array}$ \\
\hline 195 & Arachnocephalus vestitus A. Costa, 1855 & $\mathrm{LC}$ & & Italian peninsula, Sicily, and Sardinia \\
\hline 196 & $\begin{array}{l}\text { Pseudomogoplistes squamiger (Fischer, } \\
1853 \text { ) }\end{array}$ & LC & & Italian peninsula, Sicily, and Sardinia \\
\hline \multicolumn{5}{|c|}{ Myrmecophilidae } \\
\hline 197 & $\begin{array}{l}\text { Myrmecophilus (Myrmecophilus) } \\
\text { acervorum (Panzer, 1799) }\end{array}$ & LC & & North Italy and Sicily \\
\hline 198 & $\begin{array}{l}\text { Myrmecophilus (Myrmecophilus) } \\
\text { aequispina Chopard, } 1923\end{array}$ & LC & & North-west Italy \\
\hline 199 & $\begin{array}{l}\text { Myrmecophilus (Myrmecophilus) baronii } \\
\text { Baccetti, } 1966\end{array}$ & NT & & $\begin{array}{l}\text { Is. of Pantelleria (Sicily); also Malta and } \\
\text { Tunisia }\end{array}$ \\
\hline 200 & $\begin{array}{l}\text { Myrmecophilus (Myrmecophilus) fuscus } \\
\text { Stalling, } 2013\end{array}$ & LC & & Sicily \\
\hline 201 & $\begin{array}{l}\text { Myrmecophilus (Myrmecophilus) } \\
\text { myrmecophilus (Savi, 1819) }\end{array}$ & LC & & Italian peninsula, Sicily, and Sardinia \\
\hline 202 & $\begin{array}{l}\text { Myrmecophilus (Myrmophilina) ochraceus } \\
\text { (Fischer, 1854) }\end{array}$ & LC & & South Italy, Sicily, and Sardinia \\
\hline \multicolumn{5}{|c|}{ Gryllotalpidae } \\
\hline 203 & $\begin{array}{l}\text { Gryllotalpa cossyrensis Baccetti et Capra, } \\
1978\end{array}$ & $\mathrm{VU}$ & $\mathrm{E}$ & Is. Pantelleria (Sicily) \\
\hline 204 & Gryllotalpa gryllotalpa (Linnaeus, 1758) & LC & & Central-north Italy \\
\hline 205 & $\begin{array}{l}\text { Gryllotalpa octodecim Baccetti et Capra, } \\
1978\end{array}$ & DD & $\mathrm{E}$ & North-west Italy, Sardinia \\
\hline 206 & $\begin{array}{l}\text { Gryllotalpa quindecim Baccetti et Capra, } \\
1978\end{array}$ & LC & $\mathrm{E}$ & South Italy, Sicily \\
\hline 207 & $\begin{array}{l}\text { Gryllotalpa sedecim Baccetti et Capra, } \\
1978\end{array}$ & LC & $E$ & North-west Italy, Sardinia \\
\hline 208 & $\begin{array}{l}\text { Gryllotalpa septemdecimchromosomica } \\
\text { Ortiz, } 1958\end{array}$ & DD & & Central and north-west Italy \\
\hline 209 & $\begin{array}{l}\text { Gryllotalpa viginti Baccetti et Capra, } \\
1978\end{array}$ & DD & $E$ & Liguria \\
\hline 210 & Gryllotalpa vigintiunum Baccetti, 1991 & DD & $\mathrm{E}$ & Sardinia \\
\hline \multicolumn{5}{|c|}{ Tetrigidae } \\
\hline 211 & Paratettix meridionalis (Rambur, 1838) & LC & & Italian peninsula, Sicily, Sardinia \\
\hline
\end{tabular}




\begin{tabular}{|c|c|c|c|c|}
\hline 212 & Tetrix b. bipunctata (Linnaeus, 1758) & LC & & North Italy \\
\hline 213 & Tetrix bipunctata kraussi (Saulcy, 1888) & LC & & Italian peninsula, Sicily, and Sardinia \\
\hline 214 & Tetrix bolivari (Saulcy, 1901) & LC & & North-east and South Italy \\
\hline 215 & Tetrix ceperoi (Bolívar, 1887) & LC & & Italian peninsula, Sicily, and Sardinia \\
\hline 216 & $\begin{array}{l}\text { Tetrix depressa (Brisout de Barneville, } \\
1848 \text { ) }\end{array}$ & LC & & Italian peninsula, Sicily, and Sardinia \\
\hline 217 & Tetrix subulata (Linnaeus, 1758) & LC & & Italian peninsula, Sicily, and Sardinia \\
\hline 218 & Tetrix temuicornis (Sahlberg, 1893) & LC & & Central and north Italy \\
\hline 219 & Tetrix tuerki (Krauss, 1876) & $\mathrm{VU}$ & & North Italy \\
\hline \multicolumn{5}{|c|}{ Trydactilidae } \\
\hline 220 & Xya variegata (Latreille, 1809) & LC & & Italian peninsula \\
\hline \multicolumn{5}{|c|}{ Pyrgomorphidae } \\
\hline 221 & Pyrgomorpha c. conica (Olivier, 1791) & LC & & Sicily and Sardinia \\
\hline \multicolumn{5}{|c|}{ Pamphagidae } \\
\hline 222 & $\begin{array}{l}\text { Pamphagus marmoratus Burmeister, } \\
1838\end{array}$ & LC & $\mathrm{E}$ & Sicily \\
\hline 223 & $\begin{array}{l}\text { Pamphagus ortolanii Cusimano et Massa, } \\
1977\end{array}$ & NT & $\mathrm{E}$ & Is. of Lampedusa (Sicily) \\
\hline 224 & $\begin{array}{l}\text { Pamphagus sardeus (Herrich-Schaeffer, } \\
\text { 1840) }\end{array}$ & LC & $\mathrm{E}$ & Sardinia \\
\hline 225 & Acinipe calabra (O.G. Costa, 1828) & LC & & Calabria, Sicily \\
\hline 226 & $\begin{array}{l}\text { Acinipe galvagnii Cusimano et Massa, } \\
1977\end{array}$ & NT & $\mathrm{E}$ & Egadi Is. and west Sicily \\
\hline 227 & Ocneridia nigropunctata (Lucas, 1849) & LC & & Sicily \\
\hline 228 & Prionotropis appula (O.G. Costa, 1836) & LC & $\mathrm{E}$ & South Italy \\
\hline 229 & Prionotropis hystrix (Germar, 1817) & $\mathrm{VU}$ & & North-east Italy \\
\hline \multicolumn{5}{|c|}{ Acrididae } \\
\hline 230 & Podisma d. dechambrei Leproux, 1951 & LC & $\mathrm{E}$ & North-west Italy \\
\hline 231 & Podisma dechambrei melisi Baccetti, 1954 & LC & $\mathrm{E}$ & Apuane Alps, Tuscan-Emilian Apennines \\
\hline 232 & Podisma eitschbergeri Harz, 1973 & DD & $\mathrm{E}$ & Piedmont \\
\hline 233 & Podisma emiliae Ramme, 1926 & $\mathrm{CR}$ & $\mathrm{E}$ & Tuscan-Emilian Apennines \\
\hline 234 & Podisma goidanichi (Baccetti, 1958) & EN & $\mathrm{E}$ & Gran Sasso, central Apennines \\
\hline 235 & Podisma magdalenae Galvagni, 1971 & $\mathrm{CR}$ & $\mathrm{E}$ & Marche \\
\hline 236 & Podisma p. pedestris (Linnaeus, 1758) & LC & & North Italy \\
\hline
\end{tabular}




\begin{tabular}{|c|c|c|c|c|}
\hline 237 & Podisma pedestris caprai Salfi, 1935 & $\mathrm{LC}$ & $\mathrm{E}$ & Piedmont \\
\hline 238 & Podisma pedestris nadigi Harz, 1975 & LC & $\mathrm{E}$ & Alps \\
\hline 239 & Podisma ruffoi Baccetti, 1971 & EN & $\mathrm{E}$ & Central Apennines \\
\hline 240 & Podisma silvestrii Salfi, 1935 & $\mathrm{CR}$ & $\mathrm{E}$ & Central Apennines \\
\hline 241 & Bohemanella f. frigida (Bohemann, 1846) & LC & & North Italy \\
\hline 242 & $\begin{array}{l}\text { Italopodisma a. acuminata (La Greca, } \\
\text { 1969) }\end{array}$ & LC & $\mathrm{E}$ & Mt. Greco and Mt. Pratello, Abruzzo \\
\hline 243 & $\begin{array}{l}\text { Italopodisma acuminata marsicana (La } \\
\text { Greca, 1969) }\end{array}$ & LC & $\mathrm{E}$ & $\begin{array}{l}\text { Mt. Capraro, Mt. Marsicano, Mt. } \\
\text { Palombo, Abruzzo }\end{array}$ \\
\hline 244 & Italopodisma baccettii (La Greca, 1969) & $\mathrm{CR}$ & $\mathrm{E}$ & Gran Sasso, Central Apennines \\
\hline 245 & $\begin{array}{l}\text { Italopodisma costae (Targioni Tozzetti, } \\
\text { 1881) }\end{array}$ & LC & $\mathrm{E}$ & $\begin{array}{l}\text { Mt. Morrone Majella, Mt. Majelletta, } \\
\text { Abruzzo }\end{array}$ \\
\hline 246 & Italopodisma ebneri (La Greca, 1954) & $\mathrm{CR}$ & $\mathrm{E}$ & Reatini Mts., Latium \\
\hline 247 & Italopodisma fiscellana (La Greca, 1954) & EN & $\mathrm{E}$ & Central Apennines \\
\hline 248 & Italopodisma lagrecai (Galvagni, 1973) & $\mathrm{CR}$ & $\mathrm{E}$ & Central Apennines \\
\hline 249 & Italopodisma lucianae (Baccetti, 1959) & $\mathrm{CR}$ & $\mathrm{E}$ & Mt. Majella, Central Apennines \\
\hline 250 & Italopodisma samnitica (La Greca, 1954) & EN & $\mathrm{E}$ & Central Apennines \\
\hline 251 & $\begin{array}{l}\text { Italopodisma t. trapezoidalis (La Greca, } \\
\text { 1966) }\end{array}$ & EN & $\mathrm{E}$ & La Meta Mts., Central Apennines \\
\hline 252 & $\begin{array}{l}\text { Italopodisma trapezoidalis aprutiana (La } \\
\text { Greca, 1969) }\end{array}$ & EN & $\mathrm{E}$ & Mt. Marsicano, Abruzzo \\
\hline 253 & $\begin{array}{l}\text { Italopodisma trapezoidalis curvula (La } \\
\text { Greca, 1969) }\end{array}$ & EN & $\mathrm{E}$ & $\begin{array}{l}\text { Ernici and Simbruini Mts., Central } \\
\text { Apennines }\end{array}$ \\
\hline 254 & $\begin{array}{l}\text { Epipodisma pedemontana (Brunner, } \\
\text { 1882) }\end{array}$ & LC & $\mathrm{E}$ & Northern Alps \\
\hline 255 & Kisella alpina (Kollar, 1833) & LC & $\mathrm{E}$ & North-western Alps \\
\hline 256 & Kisella irena (Fruhstorfer, 1921) & LC & $\mathrm{E}$ & North-eastern Alps \\
\hline 257 & Kisella subalpina (Fischer, 1850) & LC & $\mathrm{E}$ & Aosta Valley \\
\hline 258 & $\begin{array}{l}\text { Nadigella } f . \text { formosanta (Fruhstorfer, } \\
\text { 1921) }\end{array}$ & LC & $E$ & North Italy \\
\hline 259 & Nadigella formosanta bessae Nadig, 1989 & LC & $\mathrm{E}$ & Eastern Alps \\
\hline 260 & Pseudoprumna baldensis (Krauss, 1883) & EN & $\mathrm{E}$ & Central Alps \\
\hline 261 & Micropodisma salamandra (Fischer, 1854) & LC & & North-eastern Alps \\
\hline 262 & Chortopodisma cobellii (Krauss, 1883) & EN & $\mathrm{E}$ & North-eastern Alps \\
\hline 263 & Pseudopodisma fieberi (Scudder, 1898) & LC & & North-eastern Alps \\
\hline 264 & $\begin{array}{l}\text { Odontopodisma decipiens insubrica } \\
\text { Nadig, } 1980\end{array}$ & LC & $\mathrm{E}$ & North-western Alps \\
\hline
\end{tabular}




\begin{tabular}{|c|c|c|c|c|}
\hline 265 & Odontopodisma fallax Ramme, 1951 & $\mathrm{LC}$ & & North-eastern Alps \\
\hline 266 & Odontopodisma schmidti (Fieber, 1853) & LC & & North-eastern Alps \\
\hline 267 & Pezotettix giornae (Rossi, 1794) & LC & & Italian Peninsula, Sicily, and Sardinia \\
\hline 268 & $\begin{array}{l}\text { Calliptamus } b \text {. barbarus (O.G. Costa, } \\
\text { 1836) }\end{array}$ & LC & & Italian Peninsula, Sicily, and Sardinia \\
\hline 269 & Calliptamus i. italicus (Linnaeus, 1758) & $\mathrm{LC}$ & & Italian Peninsula, Sicily, and Sardinia \\
\hline 270 & Calliptamus siciliae Ramme, 1927 & $\mathrm{LC}$ & & Italian Peninsula, Sicily, and Sardinia \\
\hline 271 & Calliptamus wattemwyliamus (Pantel, 1896) & $\mathrm{LC}$ & & Liguria \\
\hline 272 & $\begin{array}{l}\text { Eyprepocnemis p. plorans (Charpentier, } \\
1825 \text { ) }\end{array}$ & $\mathrm{LC}$ & & South Italy, Sicily, and Sardinia \\
\hline 273 & Heteracris adspersa massai Galvagni, 1978 & VU & & Sicily and Sardinia \\
\hline 274 & Heteracris anmulosa (Walker, 1870) & EN & & Sicily and Sardinia \\
\hline 275 & Anacridium aegyptium (Linnaeus, 1764) & $\mathrm{LC}$ & & Italian Peninsula, Sicily, and Sardinia \\
\hline 276 & Schistocerca gregaria (Forskål, 1775) & $\mathrm{LC}$ & & Occasional throughout all Italy \\
\hline 277 & Tropidopola c. cylindrica (Marshall, 1836) & VU & & Central-south Italy, Sicily, and Sardinia \\
\hline 278 & $\begin{array}{l}\text { Tropidopola graeca transjonica La Greca, } \\
1964\end{array}$ & VU & $\mathrm{E}$ & South Italy \\
\hline 279 & Acrida ungarica mediterranea Dirsh, 1949 & $\mathrm{LC}$ & & Italian Peninsula, Sicily, and Sardinia \\
\hline 280 & Acrida turrita Linnaeus, 1758 & $\mathrm{LC}$ & & Central Italy, Sicily, and Sardinia \\
\hline 281 & Truxalis nasuta (Linnaeus, 1758) & $\mathrm{LC}$ & & Central Italy, Sicily, and Sardinia \\
\hline 282 & $\begin{array}{l}\text { Calephorus compressicornis (Latreille, } \\
1804 \text { ) }\end{array}$ & $\mathrm{LC}$ & & South Italy and Sicily \\
\hline 283 & Psophus stridulus (Linnaeus, 1758) & $\mathrm{LC}$ & & Central-north Italy \\
\hline 284 & $\begin{array}{l}\text { Bryodemella } t . \text { tuberculata (Fabricius, } \\
1780 \text { ) }\end{array}$ & VU & & Lombardy and Liguria \\
\hline 285 & Celes $v$. variabilis (Pallas, 1771) & NT & & North-east Italy \\
\hline 286 & $\begin{array}{l}\text { Locusta migratoria cinerascens Fabricius, } \\
1781\end{array}$ & $\mathrm{LC}$ & & Italian Peninsula, Sicily, and Sardinia \\
\hline 287 & Oedaleus d. decorus (Germar, 1826) & $\mathrm{LC}$ & & Italian Peninsula, Sicily, and Sardinia \\
\hline 288 & Oedaleus senegalensis (Krauss, 1877) & LC & & Sardinia \\
\hline 289 & Oedipoda c. caerulescens (Linnaeus, 1758) & $\mathrm{LC}$ & & Italian Peninsula and Sicily \\
\hline 290 & $\begin{array}{l}\text { Oedipoda caerulescens sardeti Defaut, } \\
2006\end{array}$ & $\mathrm{LC}$ & $\mathrm{E}$ & Sardinia and Corsica \\
\hline 291 & $\begin{array}{l}\text { Oedipoda cynthiae Fontana, Buzzetti et } \\
\text { Massa, } 2019\end{array}$ & VU? & E & South Italy (Apulia) \\
\hline
\end{tabular}




\begin{tabular}{|c|c|c|c|c|}
\hline 292 & Oedipoda f. fuscocincta Lucas, 1849 & LC & & South Italy and Sicily \\
\hline 293 & Oedipoda fuscocincta morini Defaut, 2005 & $\mathrm{LC}$ & $\mathrm{E}$ & Sardinia and Corsica \\
\hline 294 & Oedipoda g. germanica ${ }^{I}$ (Latreille, 1804) & $\mathrm{LC}$ & & Italian peninsula and Sicily \\
\hline 295 & Oedipoda miniata mauritanica Lucas, 1849 & LC & & Sicily and Sardinia \\
\hline 296 & $\begin{array}{l}\text { Sphingonotus caerulans caerulans } \\
\text { (Linnaeus, 1767) }\end{array}$ & $\mathrm{LC}$ & & Italian peninsula and Sicily \\
\hline 297 & Sphingonotus c. candidus A. Costa, 1888 & NT & $\mathrm{E}$ & Sardinia \\
\hline 298 & Sphingonotus corsicus Chopard, 1924 & $\mathrm{LC}$ & & Sardinia and Corsica \\
\hline 299 & $\begin{array}{l}\text { Sphingonotus e. eurasius Mishtshenko, } \\
1936\end{array}$ & DD & & Is. of Lampedusa (Sicily) \\
\hline 300 & $\begin{array}{l}\text { Sphingonotus obscuratus lameerei Finot, } \\
1902\end{array}$ & NA & & Is. of Lampedusa (Sicily) \\
\hline 301 & Sphingonotus personatus Zanon, 1926 & EN & $\mathrm{E}$ & Italian peninsula and Sicily \\
\hline 302 & Sphingonotus r. rubescens (Walker, 1870) & $\mathrm{LC}$ & & Sardinia and Is. of Lampedusa (Sicily) \\
\hline 303 & Sphingonotus uvarovi Chopard, 1924 & EN & $\mathrm{E}$ & Sardinia and Corsica \\
\hline 304 & Acrotylus fischeri Azam, 1901 & $\mathrm{LC}$ & & North-west Italy \\
\hline 305 & Acrotylus i. insubricus (Scopoli, 1786) & $\mathrm{LC}$ & & Italian Peninsula, Sicily, and Sardinia \\
\hline 306 & Acrotylus longipes (Charpentier, 1845) & NT & & South Italy and Sicily \\
\hline 307 & $\begin{array}{l}\text { Acrotylus patruelis (Herrich-Schaeffer, } \\
\text { 1838) }\end{array}$ & $\mathrm{LC}$ & & Italian Peninsula, Sicily, and Sardinia \\
\hline 308 & Aiolopus s. simulatrix (Walker, 1870) & DD & & Sardinia \\
\hline 309 & Aiolopus s. strepens (Latreille, 1804) & $\mathrm{LC}$ & & Italian Peninsula, Sicily, and Sardinia \\
\hline 310 & Aiolopus t. thalassinus (Fabricius, 1781) & $\mathrm{LC}$ & & Italian Peninsula, Sicily, and Sardinia \\
\hline 311 & Epacromius c. coerulipes (Ivanov, 1887) & NT & & North-east Italy \\
\hline 312 & $\begin{array}{l}\text { Epacromius t. tergestimus (Charpentier, } \\
1825 \text { ) }\end{array}$ & $\mathrm{LC}$ & & North-east Italy \\
\hline 313 & $\begin{array}{l}\text { Epacromius tergestimus ponticus Karny, } \\
1907\end{array}$ & $\mathrm{LC}$ & & Veneto \\
\hline 314 & Platypygius platypygius (Pantel, 1886) & EN & & Sicily and Sardinia \\
\hline 315 & $\begin{array}{l}\text { Mecostethus p. parapleurus (Hagenbach, } \\
1822 \text { ) }\end{array}$ & LC & & North Italy \\
\hline 316 & Stethophyma grossum (Linnaeus, 1758) & $\mathrm{LC}$ & & North Italy \\
\hline 317 & $\begin{array}{l}\text { Paracinema tricolor bisignata } \\
\text { (Charpentier, 1825) }\end{array}$ & $\mathrm{LC}$ & & Italian Peninsula, Sicily, and Sardinia) \\
\hline \multicolumn{5}{|c|}{$\begin{array}{l}{ }^{1} \text { Molecular studies have shown that in Italy } O \text {. germanica is represented by two species, the true } O . \text { germanica, } \\
\text { living north of the Po river, and a probable new species, up to date undescribed, in the rest of the Italian peninsula } \\
\text { (Axel Hochkirch, pers. comm.). }\end{array}$} \\
\hline
\end{tabular}




\begin{tabular}{|c|c|c|c|c|}
\hline 318 & Duroniella lucasii (Bolívar, 1881) & LC & & Sardinia \\
\hline 319 & $\begin{array}{l}\text { Brachycrotaphus tryxalicerus (Fischer, } \\
1854)\end{array}$ & LC & & Sicily and Aeolian Is. \\
\hline 320 & Ochrilidia nuragica Massa, 1994 & EN & $\mathrm{E}$ & Sardinia \\
\hline 321 & Ochrilidia sicula (Salfi, 1931) & EN & $\mathrm{E}$ & Sicily \\
\hline 322 & Arcyptera (Arcyptera) fusca (Pallas, 1773) & LC & & Central-north Italy \\
\hline 323 & $\begin{array}{l}\text { Arcyptera (Pararcyptera) alzonai Capra, } \\
1938\end{array}$ & EN & $\mathrm{E}$ & North-west Alps \\
\hline 324 & $\begin{array}{l}\text { Arcyptera (Pararcyptera) m. microptera } \\
\text { (Fischer, 1833) }\end{array}$ & LC & & Friuli Venezia Giulia and south Italy \\
\hline 325 & Ramburiella turcomana (Fischer, 1846) & LC & & South Italy \\
\hline 326 & Chrysochraon beybienkoi Galvagni, 1968 & CR & $\mathrm{E}$ & Calabria \\
\hline 327 & Chrysochraon d. dispar (Germar, 1835) & LC & & North-east Italy \\
\hline 328 & Chrysochraon dispar giganteus Harz, 1975 & LC & & North-east Italy \\
\hline 329 & Euthystira brachyptera (Ocskay, 1826) & LC & & Alps and Apennines \\
\hline 330 & Dociostaurus g. genei (Ocskay, 1832) & LC & & Italian peninsula \\
\hline 331 & $\begin{array}{l}\text { Dociostaurus jagoi occidentalis Soltani, } \\
1978\end{array}$ & LC & & Sardinia \\
\hline 332 & $\begin{array}{l}\text { Dociostaurus maroccanus (Thunberg, } \\
1815 \text { ) }\end{array}$ & LC & & Central-south Italy, Sicily, and Sardinia \\
\hline 333 & Dociostaurus minutus La Greca, 1962 & EN & $\mathrm{E}$ & Sicily \\
\hline 334 & $\begin{array}{l}\text { Omocestus (Omocestus) rufipes } \\
\text { (Zetterstedt, 1821) }\end{array}$ & LC & & Italian Peninsula, Sicily, and Sardinia \\
\hline 335 & $\begin{array}{l}\text { Omocestus (Omocestus) viridulus } \\
\text { (Linnaeus, 1758) }\end{array}$ & LC & & Alps and northern Apennines \\
\hline 336 & $\begin{array}{l}\text { Omocestus (Omocestus) africamus Harz, } \\
1970\end{array}$ & LC & & Is. of Pantelleria (Sicily) \\
\hline 337 & $\begin{array}{l}\text { Omocestus (Omocestus) h. haemorrhoidalis } \\
\text { (Charpentier, 1825) }\end{array}$ & LC & & Italian peninsula \\
\hline 338 & $\begin{array}{l}\text { Omocestus (Omocestus) lopadusae La } \\
\text { Greca, } 1973\end{array}$ & LC & $\mathrm{E}$ & Is. of Lampedusa (Sicily) \\
\hline 339 & $\begin{array}{l}\text { Omocestus (Omocestus) Petraeus (Brisout, } \\
1855 \text { ) }\end{array}$ & LC & & Italian peninsula and Sardinia \\
\hline 340 & $\begin{array}{l}\text { Omocestus (Omocestus) raymondi (Yersin, } \\
1863 \text { ) }\end{array}$ & LC & & Liguria, Latium, and Calabria \\
\hline 341 & $\begin{array}{l}\text { Omocestus (Omocestus) uvarovi Zanon, } \\
1926\end{array}$ & EN & $\mathrm{E}$ & South Italy \\
\hline
\end{tabular}




\begin{tabular}{|c|c|c|c|c|}
\hline 342 & Stenobothrus apenninus Ebner, 1915 & LC & $\mathrm{E}$ & Apennines \\
\hline 343 & $\begin{array}{llll}\text { Stenobothrus cotticus (Kruseman et } \\
\text { Jeekel, 1967) }\end{array}$ & NT & $\mathrm{E}$ & North-western Alps \\
\hline 344 & Stenobothrus fischeri (Eversmann, 1848) & LC & & Alps and Apennines \\
\hline 345 & Stenobothrus l. lineatus (Panzer, 1796) & $\mathrm{LC}$ & & Italian peninsula and Sicily \\
\hline 346 & $\begin{array}{l}\text { Stenobothrus n. nigromaculatus (Herrich- } \\
\text { Schaeffer, 1840) }\end{array}$ & LC & & Italian peninsula \\
\hline 347 & $\begin{array}{l}\text { Stenobothrus rubicundulus Kruseman et } \\
\text { Jeekel, } 1967\end{array}$ & LC & & Central-north Italy \\
\hline 348 & Stenobothrus s. stigmaticus (Rambur, 1838) & LC & & North-east Italy \\
\hline 349 & Stenobothrus ursulae Nadig, 1986 & VU & $\mathrm{E}$ & North-western Alps \\
\hline 350 & Gomphocerus s. sibiricus (Linnaeus, 1767) & LC & & Alps and Apennines \\
\hline 351 & Gomphocerippus rufus (Linnaeus, 1758) & LC & & Italian peninsula and Sardinia \\
\hline 352 & Aeropedellus $v$. variegatus (Fischer, 1846) & EN & & Alps \\
\hline 353 & $\begin{array}{l}\text { Myrmeleotettix m. maculatus (Thunberg, } \\
1815 \text { ) }\end{array}$ & LC & & Italian peninsula and Sicily \\
\hline 354 & Stauroderus s. scalaris (Fischer, 1846) & LC & & Alps and Apennines \\
\hline 355 & $\begin{array}{l}\text { Pseudochorthippus montanus (Charpentier, } \\
1825 \text { ) }\end{array}$ & LC & & Trentino Alto Adige \\
\hline 356 & $\begin{array}{l}\text { Pseudochorthippus p. parallehus } \\
\text { (Zetterstedt, 1821) }\end{array}$ & LC & & Alps and Apennines \\
\hline 357 & $\begin{array}{l}\text { Chorthippus (Chorthippus) dichrous } \\
\text { (Eversmann, 1859) }\end{array}$ & LC & & Central Italy \\
\hline 358 & $\begin{array}{l}\text { Chorthippus (Chorthippus) d. dorsatus } \\
\text { (Zetterstedt, 1821) }\end{array}$ & LC & & Central-North Italy, Sardinia \\
\hline 359 & $\begin{array}{l}\text { Chorthippus (Chorthippus) dorsatus } \\
\text { garganicus Jannone, } 1937\end{array}$ & LC & $\mathrm{E}$ & Apulia \\
\hline 360 & $\begin{array}{l}\text { Chorthippus (Chorthippus) karelini } \\
\text { bruttius Fontana et La Greca, } 1999\end{array}$ & LC & $\mathrm{E}$ & South Italy \\
\hline 361 & $\begin{array}{l}\text { Chorthippus (Glyptobothrus) a. alticola } \\
\text { Ramme, } 1921\end{array}$ & LC & $\mathrm{E}$ & North-eastern Alps \\
\hline 362 & $\begin{array}{l}\text { Chorthippus (Glyptobothrus) a. apricarius } \\
\text { (Linnaeus, 1758) }\end{array}$ & LC & & Central-north Italy \\
\hline 363 & $\begin{array}{l}\text { Chorthippus (Glyptobothrus) b. biguttulus } \\
\text { (Linnaeus, 1758) }\end{array}$ & LC & & North Italy \\
\hline 364 & $\begin{array}{l}\text { Chorthippus (Glyptobothrus) bornhalmi } \\
\text { Harz, } 1971\end{array}$ & LC & & Carso Triestino (Friuli Venezia Giulia) \\
\hline 365 & $\begin{array}{l}\text { Chorthippus (Glyptobothrus) b. brunneus } \\
\text { (Thunberg, 1815) }\end{array}$ & LC & & Italian peninsula and Sardinia \\
\hline
\end{tabular}




\begin{tabular}{|c|c|c|c|c|}
\hline 366 & $\begin{array}{l}\text { Chorthippus (Glyptobothrus) brunneus } \\
\text { raggei (La Greca, Di Mauro, Viglianisi et } \\
\text { Monello, 2000) }\end{array}$ & LC & $\mathrm{E}$ & Sicily \\
\hline 367 & $\begin{array}{l}\text { Chorthippus (Glyptobothrus) cialancensis } \\
\text { Nadig, } 1986\end{array}$ & $\mathrm{LC}$ & $\mathrm{E}$ & North-western Alps \\
\hline 368 & $\begin{array}{l}\text { Chorthippus (Glyptobothrus) eisentrauti } \\
\text { Ramme, } 1931\end{array}$ & $\mathrm{LC}$ & & North Italy \\
\hline 369 & $\begin{array}{l}\text { Chorthippus (Glyptobothrus) messinai (La } \\
\text { Greca, Di Mauro, Viglianisi et Monello, } \\
\text { 2000) }\end{array}$ & $\mathrm{LC}$ & $\mathrm{E}$ & Sicily \\
\hline 370 & $\begin{array}{l}\text { Chorthippus (Glyptobothrus) mollis } \\
\text { ignifer Ramme, } 1923\end{array}$ & LC & $\mathrm{E}$ & Northern Alps \\
\hline 371 & $\begin{array}{l}\text { Chorthippus (Glyptobothrus) pullus } \\
\text { (Philippi, 1830) }\end{array}$ & LC & & North Italy \\
\hline 372 & $\begin{array}{l}\text { Chorthippus (Glyptobothrus) rubratibialis } \\
\text { Schmidt, } 1978\end{array}$ & $\mathrm{LC}$ & $\mathrm{E}$ & Italian peninsula \\
\hline 373 & $\begin{array}{l}\text { Chorthippus (Glyptobothrus) saulcyi } \\
\text { daimei (Azam, 1893) }\end{array}$ & LC & $\mathrm{E}$ & North-western Alps \\
\hline 374 & $\begin{array}{l}\text { Chorthippus (Glyptobothrus) trinacriae } \\
\text { (La Greca, Di Mauro, Viglianisi et } \\
\text { Monello, 2000) }\end{array}$ & LC & $\mathrm{E}$ & Sicily \\
\hline 375 & $\begin{array}{l}\text { Chorthippus (Glyptobothrus) } v . \quad \text { vagans } \\
\text { (Eversmann, 1848) }\end{array}$ & LC & & Italian peninsula \\
\hline 376 & Italohippus albicornis (La Greca, 1948) & EN & $\mathrm{E}$ & Central Apennines \\
\hline 377 & Italohippus modestus (Ebner, 1915) & VU & $\mathrm{E}$ & Central Apennines \\
\hline 378 & Italohippus monticola (Ebner, 1915) & EN & $\mathrm{E}$ & Central Apennines \\
\hline 379 & $\begin{array}{l}\text { Euchorthippus } \quad \text { albolineatus } \quad \text { siculus } \\
\text { Ramme, } 1927\end{array}$ & LC & $\mathrm{E}$ & Sicily \\
\hline 380 & Euchorthippus declivus (Brisout, 1848) & $\mathrm{LC}$ & & Italian peninsula and Sardinia \\
\hline 381 & Euchorthippus elegantulus Zeuner, 1940 & LC & & Liguria \\
\hline 382 & $\begin{array}{l}\text { Euchorthippus sardous Nadig in Nadig et } \\
\text { Nadig, } 1933\end{array}$ & LC & $\mathrm{E}$ & Sardinia \\
\hline
\end{tabular}

\section{ACKNOWLEDGEMENTS}

Filippo M. Buzzetti (Arzignano, Italy), Louis Cassar (University of Malta), Carmine Iorio (Bologna, Italy), Axel Hochkirch (Trier University, Germany), Roy Kleukers (Leiden, The Netherlands), Tommaso La Mantia (Palermo, Italy), Baudewijn Odé (Leiden, The Netherlands), Luigi Pizzo (International Commission for the Conservation of Atlantic
Tunas), Toni Puma (Modica, Italy), Paolo Savoldelli (Torino, Italy), Roberto Scherini (Pavia, Italy), and Luc Willemse (Leiden, The Netherlands) very kindly gave us some useful suggestions to compile this review or photographs to illustrate it. We would like also to thank Alessandro Minelli (Padua University, Italy), or his suggestions on the endemism definition, John J. Borg (Malta) and Louis Cassar, for the English revision. Finally, we are indebted to 
Piotr Kocarek (Ostrava University, Czech Republic) for his useful improvements to a previous version of this paper.

\section{REFERENCES}

Allegrucci G., Massa B., Trasatti A. \& Sbordoni V., 2013. A taxonomic revision of western Eupholidoptera bush crickets (Orthoptera: Tettigoniidae): testing the discrimination power of DNA barcode. Systematic Entomology, 39: 7-23. https://doi.org/10.1111/syen. 12031

Anderson S., 1994. Area and endemism. The Quarterly Review of Biology, 69: 451-471. https://doi.org/10. 1086/418743

Baccetti B., 1960. Notulae Orthopterologicae XIV: Descrizione di un nuovo genere cavernicolo di Ortotteri scoperto in Sardegna. Studi sassaresi, Sez. III. Annali facoltà di Agraria, 7: $13 \mathrm{p}$.

Baccetti B., 1985. Notulae orthopterologicae. 42. Su una nuova specie di Ephippiger raccolta in Somalia. Atti XIV Congresso nazionale italiano Entomologia, 149154.

Baccetti B. \& Capra F., 1959. Notulae Orthopterologicae XII: Revisione delle specie italiane del genere Dolichopoda Bol. (Orth. Rhaphidiphoridae). Redia, 44: 165-217.

Baccetti B. \& Capra F., 1970. Notulae Orthopterologicae XXVII: Nuove osservazioni sistematiche su alcune Dolichopoda italiane esaminate anche al microscopio elettronico a scansione (Orth. Rhaphidiphoridae). Memorie della Società entomologica italiana, 48: 351-367.

Baquero R.A. \& Tellería J.L., 2001. Species richness, rarity and endemicity of European mammals: a biogeographical approach. Biodiversity Conservation, 10: 29-44. Https://doi.org/10.1023/A:1016698921404

Baroni D., Bonifacino M. \& Valfiorito R., 2018. Euchorthippus elegantulus Zeuner, 1940 e Calliptamus wattenwylianus Pantel, 1896 al limite nord-orientale d'areale: due specie nuove per l'Italia (Insecta, Orthoptera, Acrididae). Doriana, Genova, 9: 1-9.

Battisti C., 2006. 'Peninsula effect' and Italian peninsula: materials for a review and implications in applied biogeography. Biogeographia, 27: 153-188. https:// doi.org/10.21426/B6110113

Battisti C., 2014. Peninsular patterns in biological diversity: historical arrangement, methodological approach and causal process. Journal natural History, https:/doi.org/10.1080/00222933.2014.925599.

Buzzetti F.M., Brizio C., Fontana P. \& Massa B., 2019. A new voice from Sardinia: Uromenus annae (Targioni-Tozzetti, 1881) (Insecta: Orthoptera: Tettigoniidae: Bradyporinae: Ephippgerini). Zootaxa, 4560:
311-320. http://dx.doi.org/10.11646/zootaxa.4560. 2.4

Cadeddu G., 1970. Acroneuroptila puddui nuova specie di grillomorfino cavernicolo della Sardegna. Bollettino della Società Sarda di Scienze Naturali, 7: 6576.

Casale A., Rampini M., Di Russo C. \& Delitala G.M., 2005. Dolichopoda muceddai Rampini \& Russo, nuova specie di una famiglia di Ortotteri nuova per la Sardegna (Orthoptera Raphidophoridae). Bollettino della Società entomologica italiana, 137: 75-92.

Cassar L.F. \& Galdies C., 2018. On the recent occurrence of Brachytrupes megacephalus (Lefèbvre, 1827) (Orthoptera Gryllidae) on Lampedusa. Il Naturalista siciliano, 42: 153-158.

Cigliano M.M., Braun H., Eades D.C. \& Otte D., online. Orthoptera Species File. Version 5.0/5.0.

Di Russo C., Carchini G. \& Sbordoni V., 1994. Life-history variation in Dolichopoda cave crickets. In: Danks H.V. (Ed.), Insect Life-cycle Polymorphism, Kluwer Academic Publishers: Dordrecht, pp. 205226.

Fanin Y., Tami F., Guzzon C., Candotto S. \& Merluzzi P., 2016. Nuove località di Zeuneriana marmorata (Fieber, 1853) (Insecta Orthoptera) in Friuli Venezia Giulia (Italia Nord-Orientale). Gortania, 37: 35-41.

Fontana P., 2001. Identità e bioacustica di Roeseliana brunneri Ramme, 1951, un endemita da tutelare (Insecta Orthoptera). Bollettino del Museo civico di Storia naturale di Venezia, 52: 59-74.

Fontana P., Buzzetti F.M., Cogo A. \& Odé B., 2002. Guida al riconoscimento e allo studio di Cavallette Grilli Mantidi e Insetti affini del Veneto. Ed. Museo Naturalistico Archeologico di Vicenza, 1-592.

Fontana P., Buzzetti F.M. \& Massa B., 2019. A new rare species of Oedipoda Latreille, 1829 (Orthoptera: Acrididae) from South Italy. Zootaxa, 4614: 50-60.

Fontana P. \& La Greca M., 1999a. Italohippus n. gen. di Gomphocerinae dell'Appennino centrale (Italia) (Insecta Orthoptera Acrididae). Atti dell'Accademia roveretana degli Agiati, 249, IX B: 5-18.

Fontana P. \& La Greca M., 1999b. Descrizione e prime osservazioni sulla bioacustica di Chorthippus bruttius sp. n. di Calabria (Italia Meridionale) (Insecta Orthoptera Acrididae). Atti dell'Accademia roveretana degli Agiati, 249, IX B: 19-35.

Fontana P., La Greca M. \& Kleukers R., 2005. Insecta Orthoptera. In: Ruffo S. \& Stoch F. (Eds.), Checklist e distribuzione della Fauna italiana (with cd Rom). Memorie del Museo civico di Storia naturale di Verona, 2a ser., Scienze della Vita, 16, pp. 137-139.

Fontana P. \& Massa B., 2000. Una nuova specie di Ephippiger Berthold, 1827 delle Madonie (Sicilia) (Insecta Orthoptera Tettigoniidae). Il Naturalista siciliano, 24: 271-280. 
Fontana P. \& Odé B., 1999. The specific status of Tettigonia silana Capra, 1936 confirmed (Insecta Orthoptera Tettigoniidae). Bollettino del Museo civico di Storia naturale di Verona, 23: 51-74.

Fontana P., Odé B. \& Malagnini V., 1999. On the identity of Decticus loudoni Ramme, 1933 (Insecta Orthoptera Tettigoniidae). Bollettino dell'Istituto di Entomologia G. Grandi dell'Università di Bologna, 53: $71-85$.

Fontana P., Odé B. \& Massa B., 2004. On the identity of Metaplastes ippolitoi and the other species of the genus Metaplastes. Memorie della Società entomologica italiana, 82: 423-440.

Fontana P. \& Pozzebon A., 2007. A new species of the genus Podisma Berthold, 1827 from Mont Ventoux and surrounding mountains (South France, Petit Alpes du Dauphiné) (Orthoptera Acrididae). Annales de la Société Entomologique de France (n. s.), 43: 926.

Gomboc S. \& Šegula B., 2005. The finding of Zeuneriana marmorata (Fieber, 1853) in Slovenia (Orthoptera: Tettigoniidae). Acta entomologica slovenica, 13: 81-92.

Grzywacz B., Heller K.G., Lehmann A.W., Warchalowscha-Sliwa E. \& Lehmann G.U.C., 2013. Chromosomal diversification in the flightless Western Mediterranean bushcricket genus Odontura (Orthoptera: Tettigoniidae: Phaneropterinae) inferred from molecular data. Journal Zoological Systematics \& Evolution Research, 52: 109-118. https: //doi.org/ 10.1111/jzs. 12046

Iorio C., Scherini R., Fontana P., Buzzetti F.M., Kleukers K., Odé B. \& Massa B., 2019. Grasshoppers \& Crickets of Italy. A photographic field guide to all the species. WBA Project, 578 pp.

Heller K.G., 2006. Song Evolution and Speciation in Bushcrickets. In: Drosopoulos S. \& Claridge M.F. (Eds.), Insect Sounds and Communication. Taylor \& Francis, Boca Raton, London, New York, pp. 137151.

Hochkirch A., Nieto A., García Criado M., Cálix M., Braud Y., Buzzetti F.M., Chobanov D., Odé B., Presa Asensio J.J., Willemse L., Zuna-Kratky T., Barranco Vega P., Bushell M., Clemente M.E., Correas J.R., Dusoulier F., Ferreira S., Fontana P., García M.D., Heller K-G., Iorgu I.Ș., Ivković S., Kati V., Kleukers R., Krištín A., Lemonnier-Darcemont M., Lemos P., Massa B., Monnerat C., Papapavlou K.P., Prunier F., Pushkar T., Roesti C., Rutschmann F., Şirin D., Skejo J., Szövényi G., Tzirkalli E., Vedenina V., Barat Domenech J., Barros F., Cordero Tapia P.J., Defaut B., Fartmann T., Gomboc S., Gutiérrez-Rodríguez J., Holuša J., Illich I., Karjalainen S., Kočárek P., Korsunovskaya O., Liana A., López H., Morin D., OlmoVidal J.M., Puskás G., Savitsky V., Stalling T. \&
Tumbrinck J., 2016. European Red List of Grasshoppers, Crickets and Bush-crickets. Publications Office of the European Union, Luxembourg. https:// doi.org/10.2779/60944

Kenyeres Z., Rácz I.A. \& Varga Z., 2009. Endemism hot spots, core areas and disjunctions in European Orthoptera. Acta zoologica cracoviensia, 52B: 189-211. https://doi.org/10.3409/azc.52b_1-2.189-211

Kleukers R., Fontana P. \& Odé B., 1997. Zeuneriana marmorata (Fieber): an endemic bushcricket from the coast of the northern Adriatic Sea (Insecta Orthoptera Tettigoniidae). Atti dell'Accademia roveretana degli Agiati, 247, 7B: 63-79.

Kleukers R., Odé B. \& Fontana P., 2010. Two new cryptic Leptophyes species from southern Italy (Orthoptera: Tettigoniidae). Zootaxa, 2506: 26-42. https: //doi.org/10.5281/zenodo.195953

La Greca M., 1949. Note sull'ortotterofauna dell'Italia meridionale. Bollettino della Società dei Naturalisti in Napoli, 57: 1-8.

La Greca M., Di Mauro C., Viglianisi F. \& Monello F., 2000. I Glyptobothrus (Insecta, Orthoptera Acridomorpha, Acrididae) di Sicilia, con descrizione di nuovi taxa. Bollettino dell'Accademia gioenia di Scienze naturali, Catania, 33: 185-222.

Lemonnier-Darcemont M. \& Darcemont C., 2015a. Peripodisma ceraunii (Orthoptera, Acrididae, Melanoplinae: Podismini), a new species of the genus Peripodisma from southern Albania. Articulata, 30: 53-62.

Lemonnier-Darcemont M. \& Darcemont C., 2015b. Additional data towards the knowledge of European Podismini Jacobson, 1905 (Orthoptera, Acrididae, Melanoplinae). Zoosystema, 37:371-379. https:// doi. org/10.5252/z2015n2a6

Marini L., Fontana P., Scotton M. \& Klimek S., 2008. Vascular plant and Orthoptera diversity in relation to grassland management and landscape composition in the European Alps. Journal of applied Ecology, 45: 361-370. https://doi.org/10.1111/j.1365-2664.2007. 01402.x

Massa B., 1982. Il gradiente faunistico nella penisola italiana e nelle Isole. Atti della Società italiana di Scienze naturali \& Museo civico di Storia naturale di Milano, 123: 353-374.

Massa B. \& Fontana P., 2011. Supraspecific taxonomy of Palaearctic Platycleidini with unarmed prosternum: a morphological approach (Orthoptera: Tettigoniidae: Tettigoniinae). Zootaxa, 2837: 1-47.

Massa B., Fontana P., Buzzetti F.M., Kleukers R. \& Odé B., 2012. Fauna d'Italia. XLVIII. Orthoptera. Calderini ed., Bologna, 563+CCXIV pp.

Massa B., Fontana P. \& Kleukers R., 2001. Italian Endemic Orthoptera. Proceedings International Conference Ortopteroid Insects, 50. 
Massa B., Fontana P. \& Odé B., 2001. Morphology, biology and bioacustics of three Sicilian endemic Orthoptera species (Insecta Orthoptera Tettigoniidae). Atti dell'Accademia roveretana degli Agiati, 251, 1B: 211-232.

Massa B., Ünal M. \& Lo Verde G., 2015. Revision of the genus Prionotropis Fieber, 1853 (Orthoptera: Pamphagidae: Thrinchinae). Zootaxa, 4059: 499-524. http://dx.doi.org/10.11646/zootaxa.4059.3.4

Médail F. \& Quézel P., 1999. Biodiversity hotspots in the Mediterranean basin: setting global conservation priorities. Conservation Biology, 13: 1510-1513. https: //doi.org/10.1046/j.1523-1739.1999.98467.x

Messina A., 1981. Sulle specie di Odontura del gruppo stenoxypha (Fieb.) (Orthoptera, Phaneropterinae). Animalia, 8: 15-26.

Minelli A., 1974. Riflessioni sull'endemismo e la vicarianza nel Regno animale. Lavori della Società italiana di Biogeografia, 4: 77-100. https://doi.org/10. 21426/ B64110082

O’Brien S.J. \& Mayr E., 1991. Bureaucratic mischief: recognizing endangered species and subspecies. Science, 251: 1187-1188. https://doi.org/10.1126/science. 251.4998 .1187

Pignatti S., 1979. I piani di vegetazione in Italia. Giornale botanico italiano, 113: 411-428. https://doi.org/10. 1080/11263507909426417

Racheli T. \& Zilli A., 1985. Modelli di distribuzione dei Lepidotteri nell'Italia meridionale. Biogeographia, 11: 165-194. Https://doi.org/10.21426/B611110302

Ragge D.R. \& Reynolds W.J., 1998. The songs of the grasshoppers and crickets of western Europe. Harley Books \& The Natural History Museum, London, 591 pp.

Sbordoni V., Allegrucci G., Caccone A., Cesaroni D., Cobolli Sbordoni M. \& De Matthaeis E., 1981. Genetic variability and divergence in cave populations of Troglophilus cavicola and T. andreinii. Evolution, 35: 226-233. https://doi.org/10.2307/2407833
Steininger F.F. \& Wessely G., 2000. From the Tethyan Ocean to the Paratethys Sea: Oligocene to Neogene Stratigraphy, Paleogeography and Paleobiogeography of the circum-Mediterranean region and the Oligocene to Neogene basin evolution in Austria. Mitteilungen Österreichische Geologische Gesellschaft, 92: 95-116.

Suc J.P., Diniz F., Leroy S., Poumot C., Bertini A., Dupont L., Clet M., Bessais E., Zheng Z., Fauquette S., \& Ferrier J., 1995. Zanclean ( Brunnsumian) to Early Piacenzian ( $\sim$ middle Reuverian) climate from $4^{\circ}$ to $54^{\circ}$ north latitude (West Africa, West Europe, and Western Mediterranean areas). Mededelingen Rijks Geologische Dienst, 52: 43-56.

Vargas J.M., Real R. \& Guerrero J.C., 1998. Biogeographical regions of the Iberian Peninsula based on freshwater fish and amphibian distributions. Ecography, 21: 371-382. https://doi.org/10.1111/j.16000587.1998.tb00402.x

Verdú J.R. \& Galante E., 2002. Climatic stress, food availability and human activity as determinants of endemism patterns in the Mediterranean region: the case of dung beetles (Coleoptera, Scarabaeoidea) in the Iberian Peninsula. Diversity \& Distribution, 8: 259-274. https://doi.org/10.1046/j1472-4642.2002. 00151.x

Warchalowscha-Sliwa E., Maryanska-Nadachowska A., Grzywacz B., Karamysheva T., Lehmann A.W., Lehmann G.U.C. \& Heller K.G., 2011. Changes in the numbers of chromosomes and sex determination system in bushcrickets of the genus Odontura (Orthoptera: Tettigoniidae: Phaneropterinae). European Journal Entomology, 108: 183-195. https://doi.org/ 10.14411/eje.2011.025

Willemse F., von Helversen O. \& Odè B., 2009. A review of Chorthippus species with angled pronotal lateral keels from Greece with special reference to transitional populations between some Peloponnesean taxa (Orthoptera, Acrididae). Zoologische Mededelingen Leiden, 83: 319-507. 